\title{
A geographical and seasonal comparison of nitrogen uptake by phytoplankton in the Southern Ocean
}

\author{
R. Philibert ${ }^{1}$, H. Waldron ${ }^{1}$, and D. Clark ${ }^{2}$ \\ ${ }^{1}$ Department of Oceanography, University of Cape Town, Cape Town, South Africa \\ ${ }^{2}$ Plymouth Marine Laboratory, Plymouth, UK \\ Correspondence to: R. Philibert (raissaphilibert@gmail.com)
}

Received: 27 June 2014 - Published in Ocean Sci. Discuss.: 14 July 2014

Revised: 2 February 2015 - Accepted: 8 February 2015 - Published: 13 March 2015

\begin{abstract}
The impact of light and nutrients (such as silicate and iron) availability on nitrogen uptake and primary production vary seasonally and regionally in the Southern Ocean. The seasonal cycle of nitrogen uptake by phytoplankton in the Southern Ocean is not fully resolved over an annual scale due to the lack of winter in situ measurements. In this study, nitrate and ammonium uptake rates were measured using ${ }^{15} \mathrm{~N}$ tracers during a winter cruise in July 2012 and a summer cruise in February-March 2013. The winter cruise consisted of two legs: leg 1 extended from Cape Town to the ice margin along the GoodHope line and leg 2 stretched from the ice margin to Marion Island. The summer cruise was mostly focused on the subantarctic zone of the Atlantic sector. In winter, nitrogen uptake rates were measured at 55 and $1 \%$ of the surface photosynthetically active radiation (sPAR). The summer uptake rates were measured at four light depths corresponding to 55, 30, 10 and 3\% sPAR. The integrated nitrate uptake rates during the winter cruise ranged from 0.17 to $5.20 \mathrm{mmolN} \mathrm{m}^{-2} \mathrm{~d}^{-1}$ (average $1.14 \mathrm{mmol} \mathrm{N} \mathrm{m}^{-2} \mathrm{~d}^{-1}$ ) while the ammonium uptake rates ranged from 0.60 to $32.86 \mathrm{mmol} \mathrm{N} \mathrm{m}^{-2} \mathrm{~d}^{-1}$ (average $6.73 \mathrm{mmol} \mathrm{N} \mathrm{m}^{-2} \mathrm{~d}^{-1}$ ). During the summer cruise, the mean-integrated nitrate uptake rate was $0.20 \mathrm{mmol} \mathrm{N} \mathrm{m}^{-2} \mathrm{~d}^{-1}$ with a range between 0.10 and $0.38 \mathrm{mmol} \mathrm{N} \mathrm{m}^{-2} \mathrm{~d}^{-1}$. The integrated ammonium uptake rate averaged $4.39 \mathrm{mmol} \mathrm{N} \mathrm{m}^{-2} \mathrm{~d}^{-1}$ and ranged from 1.12 to $9.05 \mathrm{mmol} \mathrm{N} \mathrm{m}^{-2} \mathrm{~d}^{-1}$.

The factors controlling nitrogen uptake in winter and summer were investigated. During the winter cruise, it was found that the different nitrogen uptake regimes were not separated by the fronts of the Antarctic Circumpolar Current (ACC). Light (in terms of day length) and ammonium concentration had the most influence on the nitrogen uptake. In the
\end{abstract}

summer, increases in the mixed layer depth (MLD) resulted in increased nitrogen uptake rates. This suggests that the increases in the MLD could be alleviating nutrient limitations experienced by the phytoplankton at the end of summer.

\section{Introduction}

In the Southern Ocean, low temperature, low light, strong vertical mixing and iron limitation restrict the uptake of nitrogen and ultimately phytoplankton growth. The concentrations of iron in the Southern Ocean are low due to the lack of terrestrial inputs. The role of these low iron concentrations in limiting nitrogen uptake is well-established (De Baar et al., 1990; Martin et al., 1990; Moore et al., 2007; Falkowski et al., 1998; Cochlan, 2008; Boyd et al., 2010; Boyd, 2002). Furthermore, phytoplankton in a strongly mixed environment, such as the Southern Ocean, are not exposed to light for sufficiently long periods for efficient nutrient uptake and growth (Mitchell et al., 1991; Venables and Moore, 2010). This is compounded by the low incident light. The combination of these bottom-up controls and top-down controls such as grazing (Behrenfeld, 2010) results in the high nutrients low chlorophyll conditions for which the Southern Ocean is well-known. Despite this, the Southern Ocean plays an important role in the global marine carbon cycle. Carbon fluxes in this region account for about $4 \%$ of global carbon fluxes (Takahashi et al., 2009) and $300 \mathrm{TgC} \mathrm{Cy}^{-1}$ of export production (Henson et al., 2011; Gruber et al., 2009). This is achieved through a combination of the solubility pump and the biological pump. The solubility pump encompasses the physical processes, such as mixing of surface water masses 
to the deeper layer, which remove carbon dioxide from the surface. The biological pump is driven by the sinking and subsequent sequestration of organic matter produced by phytoplankton through photosynthesis. In this process, phytoplankton convert inorganic nutrients (carbon, nitrogen and others) into organic matter (Volk and Hoffert, 1985). Given the cellular demands (Hedges et al., 2002), the elements are generally assimilated in a fixed ratio, which was first observed by Redfield (1934). This ratio is very useful in linking the various biogeochemical cycles. For instance, carbon uptake rates are often estimated by multiplying carbon export rates by the measured $\mathrm{C}: \mathrm{N}$ ratio or by the Redfield ratio. Only part of the organic carbon formed by phytoplankton is exported and sequestered below the permanent thermocline (Falkowski et al., 2003). This fraction can be estimated by distinguishing the sources of inorganic nitrogen nutrients (Dugdale and Goering, 1967; Eppley and Peterson, 1979). Nitrate was considered to be a new nutrient which is only formed outside of the euphotic zone and brought to the surface through physical processes. Ammonium and urea were considered to be regenerated nutrients formed within the euphotic zone. Nitrate being used by phytoplankton has to be in balance with the rate of organic nitrogen export for the phytoplankton to maintain itself. Therefore, the fraction of primary production fuelled by nitrate over total primary production would correspond to the amount of exported organic matter. However, equating nitrate uptake to export production is not so straightforward and accurate as it ignores potential nitrification (Yool et al., 2007), release of dissolved organic nitrogen by phytoplankton following nitrogen uptake (Bronk et al., 1994) and nitrogen fixation (Berman-Frank et al., 2001).

The Southern Ocean is subdivided by distinct frontal features which have been observed in the Antarctic Circumpolar Current (ACC) (Orsi et al., 1995). These frontal features (from north to south, the subtropical, the subantarctic and the polar fronts) separate three surface water regimes and affect the distribution of phytoplankton as well as as other biogeographical patterns (Pollard et al., 2002; Sambrotto and Mace, 2000). In addition, the deep water masses formed in the Southern Ocean play an important role in supplying nutrients to the low latitudes (Sarmiento et al., 2004). This nutrient supply to the subtropics and tropics is effectively controlled by nutrient uptake in the polar frontal zone (south of the polar front) and subantarctic zone (north of the polar front) where the Antarctic Intermediate Water and Subantarctic Mode Water are formed. The efficiency of the biological pump for carbon export and nutrient transfer to thermocline waters is still debated. In order to resolve this debate, an understanding of seasonal variations on biogeochemical features and phytoplankton productivity is needed (Boyd, 2002; Sambrotto and Mace, 2000). Given the zonation resulting from the frontal features of the ACC, the Southern Ocean is a complex region with diverse ecological provinces and the effects of seasonality vary from region to region (Le Moigne et al., 2013;
Thomalla et al., 2011a). For this, numerous studies compare nitrogen uptake based on their location with respect to the fronts (Sambrotto and Mace, 2000; Thomalla et al., 2011b; Joubert et al., 2011; Westwood et al., 2011; Cavagna et al., 2011).

There is, however, a paucity of observational data in the Southern Ocean, especially for the winter season as most cruises in the Southern Ocean have been confined to spring and summer. As a result, the influences of seasonality on phytoplankton dynamics, nitrogen uptake and consequently the efficiency of the biological pump in the Southern Ocean are still not completely resolved over an annual cycle. Researchers are turning to remote sensing and modelling in order to overcome the logistical constraints of ship-based measurements (e.g. poor spatial and temporal resolution) (Henson et al., 2011; Vichi et al., 2007) but these two approaches have their limitations. Remote-sensing data need to be calibrated against observational data and in the Southern Ocean, satellite observations for the winter season can be limited by the sun angle as well as cloud cover (Vernet et al., 2012). There is little data to initialise and validate biogeochemical models which derive primary production from environmental and physical conditions such as light availability and nutrient concentrations (Vichi et al., 2007; Bissett et al., 1999).

In this paper, nitrate $\left(\mathrm{NO}_{3}^{-}\right)$and ammonium, $\left(\mathrm{NH}_{4}^{+}\right)$uptake rates were measured in the Southern Ocean during the austral winter of 2012 and in the late summer of 2013 using ${ }^{15} \mathrm{~N}$ tracers. In winter, sampling was undertaken between South Africa and the ice margin along the GoodHope line and then between the ice margin and Marion Island. Most of the summer stations were located within the subantarctic zone of the Atlantic sector. While summer (or early autumn) rates are common, this data set is a rare instance of nitrogen uptakes rates for winter (Cota et al., 1992). Consequently estimates of nitrogen uptake are presented with the aim of investigating seasonal patterns and exploring factors affecting the biological pump in the Southern Ocean. The nitrogen uptake rates from this study are compared to rates measured in winter and other seasons to highlight the fact that nitrogen uptake in winter, while low, is still significant.

Finally, the biogeochemical factors controlling nutrient uptake by phytoplankton are explored. Given that phytoplankton respond to the biogeochemical setting and that the latter is controlled by the frontal positions, the fronts should play a role in controlling nitrogen uptake by phytoplankton. In this study, the extent to which the nitrogen uptake regime is bounded by the fronts of the ACC is examined. Using multivariate analyses, the potential factors for the variability in nitrogen uptake rates are explored to determine which ones - nutrients, light, temperature, mixed layer depth (MLD) play a more important role in regulating primary productivity. The factors controlling nitrogen uptake during the summer and winter seasons are discussed. This provides for a better mechanistic understanding of factors controlling nitrogen 
uptake by phytoplankton and can contribute to the development of biogeochemical models.

\section{Methods}

\subsection{Sampling and analytical methods}

The present study consists of two cruises which are part of the Southern Ocean Seasonal Cycle Experiment (SOSCEx). The first cruise, referred to as the winter cruise, was undertaken aboard the RV SA Agulhas II from the 10 to 29 July 2012 and consisted of two legs. Leg 1 extended from Cape Town to the ice margin along the Good Hope line. The GoodHope line is a monitoring line between South Africa and Antarctica, which was established in 2004 (Ansorge et al., 2005). Leg 2 stretched from the ice margin to Marion Island (Fig. 1). The summer cruise was conducted on board the MV SA Agulhas from the 15 February to 11 March 2013 (Thomalla et al., 2013). Nitrogen uptake rates were estimated at two stations along the GoodHope line and two process stations (A and B) within the subantarctic zone. The sampling locations for the summer cruise are shown in black in Fig. 1 . The aim of the process stations was to sample the same parcel of water repeatedly. As such, each process station consisted of several conductivity-temperature-depth (CTD) stations where nitrate uptake was measured. Process station A was initialised by deploying a float on 25 February 2013 at $42^{\circ} 39^{\prime} \mathrm{S} 8^{\circ} 41^{\prime}$ E. However, the float was deployed incorrectly and a new float had to be deployed 2 days later when this station was next occupied. This Lagrangian float measured conductivity, temperature, pressure and photosynthetically available radiation using built-in sensors. Process station B did not have a float but was sampled continuously by a glider. The latter measured the same variables as the float as well as fluorescence and two wavelengths $(\lambda=470$ and 700 ) of optical backscattering. Each dive cycle took approximately $5 \mathrm{~h}$ to complete and covered an average horizontal distance of $2.8 \mathrm{~km}$, rendering a temporal resolution of $2.5 \mathrm{~h}$ and spatial resolution of $1.4 \mathrm{~km}$ between profiles.

Temperature and salinity were measured by a rosettemounted Sea-Bird CTD sensor. Chlorophyll $a$ and oxygen measurements were obtained from calibrated Wetlab sensors attached to the same rosette. According to manufacturer specifications, the precision ranges for the rosette mounted sensors are $\pm 0.001{ }^{\circ} \mathrm{C}$ for temperature, $\pm 0.0003 \mathrm{~S} \mathrm{~m}^{-1}$ for conductivity (which is converted to salinity) and $\pm 0.02 \mu \mathrm{g} \mathrm{L}^{-1}$ for Chlorophyll $a$. During the winter cruise, the CTD was cast three times a day (06:00, 12:00 and 21:00 LT) along the GoodHope line, whereas on the track between the ice shelf and Marion Island, it was cast at pre-determined locations. Temperature profiles were also obtained from expendable bathythermographs and underway CTD deployments at $2 \mathrm{~h}$ intervals.

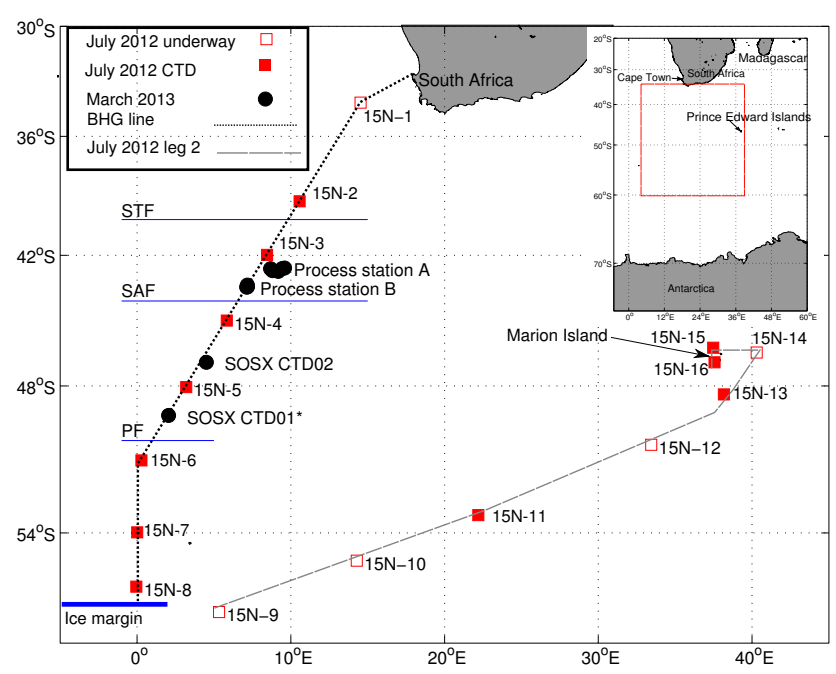

Figure 1. Cruise track for the two cruises. Leg 1 of winter cruise extended from Cape Town to the ice margin $58^{\circ} \mathrm{S}$ and leg 2 from the ice margin to Marion Island. The winter frontal and ice margin positions are indicated by the blue lines. STF represents the subtropical front, SAF the subantarctic front and PF the polar front. The black dotted line (BGH line) shows the GoodHope (also referred to as Bonus-GoodHope) line while the grey dashed line shows the cruise track on leg 2 of the winter cruise.

The study region was divided into four zones based on the temperature criteria of Orsi et al. (1995): the subtropical zone (defined as the region north of the subtropical front), the subantarctic zone (defined as north of the subantarctic front), the polar frontal zone (defined as north of polar front) and the Antarctic zone (defined as south of the polar front). The subantarctic zone was the target of the summer cruise while most of the winter stations were found in the polar frontal zone and the Antarctic zone.

Nutrient concentrations were determined on board: $\mathrm{NO}_{3}^{-}$ and $\mathrm{Si}(\mathrm{OH})_{4}$ using a Lachat QuikChem ${ }^{\circledR}$ flow-injection autoanalyser; $\mathrm{NO}_{2}^{-}$and $\mathrm{PO}_{4}^{-}$manually according to methods described by Grasshoff et al. (1983) and $\mathrm{NH}_{4}^{+}$using the fluorometric method described by Holmes et al. (1999) with improvements by Taylor et al. (2007). For the summer cruise, samples for $\mathrm{NH}_{4}^{+}$concentrations were frozen and analysed at a later stage. If there are no systematic sampling errors, the precisions of the $\mathrm{NO}_{3}^{-}+\mathrm{NO}_{2}^{-}, \mathrm{PO}_{4}^{-}$and $\mathrm{Si}(\mathrm{OH})_{4}$ concentrations are $\pm 0.04 \mu \mathrm{molL}^{-1}, \pm 0.06 \mu \mathrm{molL}^{-1}$ and $\pm 0.02 \mu \mathrm{molL}^{-1}$ respectively (Grasshoff et al., 1983). The precision of the ammonium concentration $0.06 \mu \mathrm{molL}^{-1}$ (Holmes et al., 1999).

Water samples for the measurement of $\mathrm{NO}_{3}^{-}$and $\mathrm{NH}_{4}^{+}$uptake rates were obtained at the early morning CTD stations. During the winter cruise, samples at the CTD stations were taken at the depth of the fluorescence maximum and at the $1 \%$ light depth. Alternatively, on days where the ship did not stop for an early morning CTD cast due to bad weather 
or sampling plans, samples were taken from the underway water system. Underway samples were collected from $5 \mathrm{~m}$ using a mono pump. This type of pump is recommended for supplying major research vessels with uncontaminated seawater supply as it minimises the damage to phytoplankton cells. For the summer cruise, samples were collected from four depths representing 55, 30, 10 and $3 \%$ of surface irradiance. Those light depths were determined during a cast on the afternoon prior to sample collection.

In all, $2 \mathrm{~L}$ water samples from each depth were amended with $\mathrm{Na}^{15} \mathrm{NO}_{3}\left(1 \mu \mathrm{molL} \mathrm{L}^{-1}\right)$ and ${ }^{15} \mathrm{NH}_{4} \mathrm{Cl}\left(0.1 \mu \mathrm{molL} \mathrm{L}^{-1}\right.$ in winter and $0.05 \mu \mathrm{mol} \mathrm{L}^{-1}$ in summer). These values were based on expected ambient nutrient concentrations and kept constant throughout the cruise. The tracer concentrations were between 5 and $160 \%$ of the ambient concentration for $\mathrm{NH}_{4}^{+}$and between 3 and $52 \%$ for $\mathrm{NO}_{3}^{-}$. On the winter cruise, the samples were incubated for $24 \mathrm{~h}$ on deck under simulated in situ light depths of $1 \%$ and $55 \%$ surface photosynthetically active radiation (sPAR). For underway stations, samples were only incubated at the $55 \%$ light depth. On the summer cruise, the samples were incubated for $12 \mathrm{~h}$ under simulated in situ light depths corresponding to the sampling depth (55, 30,10 and $3 \%$ sPAR). During both cruises, the temperature was kept at sea-surface temperature (SST) by using a continuous flow of seawater. The incubations were terminated by filtering onto $0.7 \mu \mathrm{m} \mathrm{GF} / \mathrm{F}$ Whatman filters (GFF). The particulate on the filter was analysed for nitrogen content and isotopic enrichment using an elemental analyser coupled to an isotope ratio mass spectrometer (IRMS). The carbon and nitrogen content were determined by comparing the response of the IRMS for each sample to that of a standard (Valine) with a known carbon and nitrogen content by weight. Crosslaboratory comparisons have shown the accuracy of this measurement to be within $1 \%$ of the true value. The relative standard deviation of the atom enrichment percent on standards with natural concentrations of $15 \mathrm{~N}$ was $0.39 \%$. This relative standard deviation is expected to be higher for enriched samples but a good estimate is not available as enriched standards were not used. The lack of an exact estimate on this precision precludes from estimating the error on the uptakes rates through error propagation. However, it is expected that the relative standard deviation for these measurements would be $\pm 10 \%$ as calculated by Cavagna et al. (2011) given the similarities in the methods.

Specific uptake rates for $\mathrm{NO}_{3}^{-}$and $\mathrm{NH}_{4}^{+}$were calculated as described by Eq. (4') from Collos (1987):

$$
v=\frac{a_{\mathrm{p}}-a_{\text {nat }}}{t \times\left(a_{\mathrm{enr}}-a_{\mathrm{nat}}\right)},
$$

where $a_{\mathrm{p}}$ is the final atom enrichment percent (AE\%) in the particulate matter, $a_{\text {nat }}$ is the natural abundance of ${ }^{15} \mathrm{~N}$ (AE\% in the particulate at the start of incubation) and $a_{\mathrm{enr}}$ is the $\mathrm{AE} \%$ of the water sample (initially labelled fraction) and $t$ is the incubation time. Absolute uptake rates were obtained by multiplying the specific uptake rate by the concentration of nitrogen (determined as described above) in the particulate matter.

In addition, a recorded volume of seawater (obtained from the same CTD cast) was filtered on a $0.7 \mu \mathrm{m}$ GFF to determine particulate organic carbon (POC) and particulate organic nitrogen (PON). The GFF was exposed to fuming $\mathrm{HCl}$ to remove all inorganic carbon. The POC and PON content were determined using the elemental analyser coupled with IRMS.

For each of the winter CTD stations, the daily nitrogen uptake rate was integrated over the MLD. The MLD was identified as the depth where the temperature differed from the surface temperature by more that $0.2^{\circ} \mathrm{C}$. For the summer, the nitrogen uptake rates were integrated over the euphotic zone and converted to a daily rate. The hourly nitrate uptake rates were multiplied by the light period at the sampling location, whereas the ammonium uptake rate was multiplied by the light period plus half of the dark period to account for dark uptake (Cavagna et al., 2011, and references therein). The average light period during the summer cruise was $14 \mathrm{~h}$. It is to be noted that the uptake rates were likely to be nonlinear through the incubation period (Elskens et al., 2005). This is a potential source of error when converting these average hourly rates to daily rates.

\subsection{Statistical analysis}

A multivariate statistics approach was employed on this data set in order to investigate the biogeochemical controls over nitrogen uptake and test the hypothesis that the nitrogen uptake regime in winter was controlled by the fronts in Southern Ocean.

The statistical approach and the interpretation of the results are based largely on material from Borcard et al. (2011). The analysis was done in $\mathrm{R}$ using the vegan package. The hypothesis tested here was whether clusters which were derived from the nitrogen uptake rates would be separated by the subtropical, subantarctic and polar fronts.

The normality of all the variables was examined using a Shapiro-Wilk test as this is a requirement for the multivariate analysis. Nitrate concentrations were found to be normal while the uptake rates, ammonium and silicic acid concentrations were normalised through a log transformation.

A cluster analysis was performed using the physical and biogeochemical variables for each station (temperature, chlorophyll, nutrients) to confirm whether these variables were constrained by the fronts. This cluster analysis was compared with a cluster analysis of the nitrogen uptake rates (response variables).

Finally, a redundancy analysis (RDA) was performed. The data were transformed as above and scaled to fit the requirements of the RDA analysis. A RDA combines a principal components analysis (which identifies the major sources of variations in a data set) to multiple linear regressions. The RDA performed here was based on a correlation matrix de- 
rived from normalised and centred data. The RDA was done twice for the winter data set: the first using the CTD stations only and the second using all the stations. Using the CTD stations (where nitrogen uptake was estimated at two light depths and for which the mixed layer depths were known) allowed for a quantification of the role of the MLD. When including the underway stations, only the $55 \%$ light depth was used and the MLD was not included as a parameter as it was not available for these stations.

For the summer cruise, an RDA on the two process stations was not possible due to the limited number of complete observations. Instead, the Spearman correlations between the uptake rates and environmental variables at the two process stations were investigated. The two stations at the polar frontal zone were likely to have different environmental controls (Thomalla et al., 2011a) and were therefore not included in this analysis. These results were also limited by the number of observations and are presented here as a qualitative investigation into the factors controlling nitrogen uptake rates.

\section{Results}

\subsection{Hydrographic data}

The hydrographic profiles for the winter cruise are provided in the Supplement while the frontal positions are indicated on Fig. 1. While the temperatures and salinity decreased with latitude, the transition at the fronts was not sharp (see Supplement). During leg 2, sampling was carried out from the ice edge to Marion Island in a straight line and then around the island in an anticlockwise direction. There was a sharp temperature transition between station $15 \mathrm{~N}-11$ and $15 \mathrm{~N}-13$, which indicated the shift between the Antarctic and polar frontal zones.

For the summer cruise, samples were taken at two process stations within the subantarctic zone as well as two CTD stations within the polar frontal zone. Temperatures through the euphotic zone at process station A (Fig. 2) were between 10 and $12{ }^{\circ} \mathrm{C}$. A mixing event occurred between the 3 and 7 March. The mixed layer depth increased from its shallowest at $37 \mathrm{~m}$ to a maximum of $76 \mathrm{~m}$. This brought colder, deeper water to the surface and reduced the average temperature. This was accompanied by a decrease in salinity. A decrease in mean chlorophyll concentrations within the euphotic zone $\left(0.70 \mathrm{mg} \mathrm{m}^{-3}\right.$ at CTD 4 to $0.42 \mathrm{mg} \mathrm{m}^{-3}$ at CTD 15) was also observed. Process station B (Fig. 2) showed cooler temperatures (between 9 and $10^{\circ} \mathrm{C}$ ) than station $\mathrm{A}$. The mixed layer depths were deeper than at process station $\mathrm{A}$ ranging from 65 to $85 \mathrm{~m}$. The mixed layer deepened between the 28 February and 4 March. Though this did not result in large differences in temperature, salinity and oxygen, there was a clear decrease in mean chlorophyll concentration from 0.51 to $0.39 \mu \mathrm{gL}^{-1}$ between these two sampling dates.
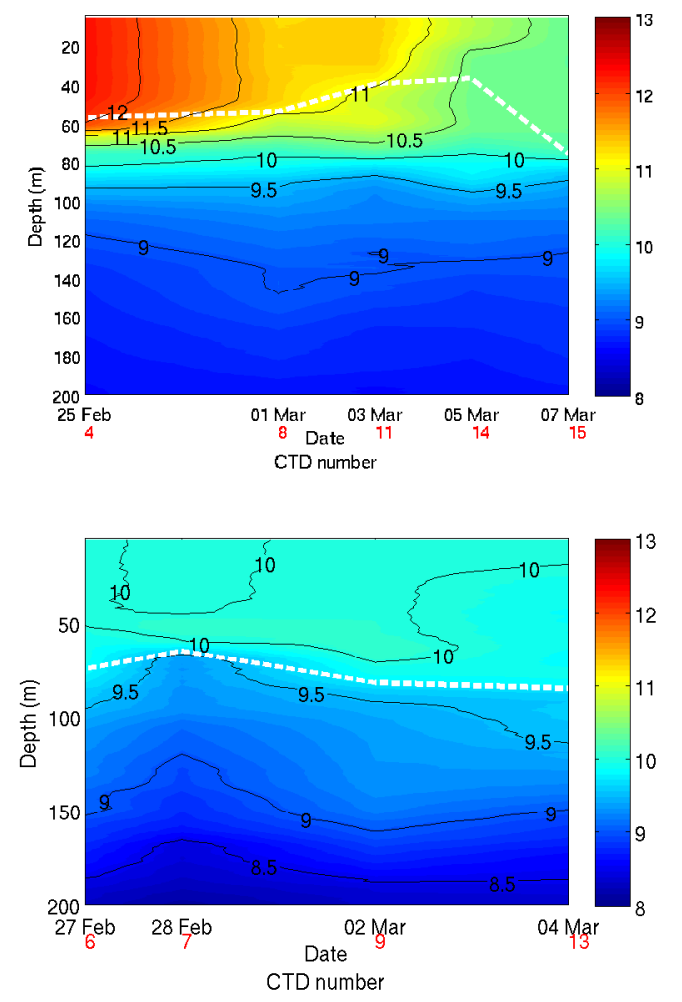

Figure 2. Temperature $\left({ }^{\circ} \mathrm{C}\right)$ profiles for the summer cruise. (a) Process station A (b) process station B. The horizontal axis shows the dates in black and the corresponding CTD (conductivitytemperature-depth) numbers in red. The white line represents the MLD (mixed layer depth). The contour lines represent the isotherms. The value of each isotherm is shown in black on the plot.

\subsection{Nitrogen uptake rates}

This section provides a short description of the nitrogen uptake rates estimated for the two seasons. Specific, absolute and depth-integrated rates are presented here. Specific nitrogen uptake rates $(v)$ allow for comparison of uptake and growth rates independent of biomass, whereas the absolute uptake rates represent the uptake in relation to the particulate nitrogen. The depth-integrated rates allow for estimates of nutrient uptake throughout the water column.

It is to be noted that samples for the regeneration of $\mathrm{NH}_{4}^{+}$ were lost and therefore isotopic dilution arising from $\mathrm{NH}_{4}^{+}$ regeneration has not been accounted for. Due to logistical constraints, urea concentrations and uptake rates were not measured despite being a potentially important fraction of regenerated production (Joubert et al., 2011). Other potential sources of regenerated production such as dissolved organic nitrogen (e.g. amino acids) were also not accounted for. These omissions in the regenerated production estimates do not affect the new production estimates but they highlight the limitations of the $f$ ratio as an indicator of carbon export as they lead to underestimates in regenerated production. The lack of nitrification rate measurements is a caveat in the 
estimate of new production from nitrate uptake. The use of nitrate uptake as a proxy for new production and carbon export is based on the assumption that all the nitrate present in the euphotic zone is formed below the permanent thermocline and brought to the surface through upwelling and vertical mixing (Eppley and Peterson, 1979). It is therefore considered a new nutrient as opposed to a regenerated nutrient like ammonium or urea, which are produced within the euphotic zone. This rests on the assumption that nitrification, the oxidation of ammonium to nitrate, is completely inhibited by light and does not occur within the euphotic zone (Eppley and Peterson, 1979; Joubert et al., 2011). This is, however, a false assumption as nitrification as well as nitrifying organisms have been observed in the euphotic zone in various regions (Yool et al., 2007). In the case of significant euphotic nitrification, part of the nitrate used by phytoplankton is likely to be part of the regenerated nutrient pool. Nitrification can also lead to the isotopic dilution of the nitrate pool and a resulting underestimate of nitrate uptake. Nitrification has been observed during summer in the Southern Ocean (Bianchi et al., 1997) and DiFiore et al. (2009) have estimated that this process could represent up to $6 \%$ of $\mathrm{NO}_{3}^{-}$ uptake during this season. The role of nitrification in replenishing nutrients over the winter season has been hypothesised previously (Sanders et al., 2007) and has been confirmed by a recent study on the natural abundances of $\delta^{15} \mathrm{~N}$ and $\delta^{18} \mathrm{O}$ (Smart et al., 2015). Equating nitrate uptake to new production also rests on the assumption that nitrogen fixation is negligible. While the contribution of nitrogen fixation was expected to be low in the Southern Ocean (Berman-Frank et al., 2001), this nevertheless brings the use of the $f$ ratio as a proxy for carbon export into question.

In addition, in this present study, the equation by Collos (1987) was used instead of the one by Dugdale and Goering (1967). The latter, which subtracts the AE\% in the particulate matter at the end of the incubation from the $\mathrm{AE} \%$ of the initially labelled pool, does not account for the use of multiple sources of nitrogen. When the phytoplankton uses an unlabelled source of nitrogen at the same time as a labelled one, the resulting enrichment in the particulate matter is underestimated. Collos (1987) has shown that the equation used here accounts for this bias.

However, there are other sources of error which are not corrected for. Part of the DIN taken up by phytoplankton is sometimes released as DON instead of being assimilated into the cells. When this is not accounted for, nitrogen uptake rates might be underestimated as this nitrogen is lost from the particulate pool (Bronk et al., 1994; Glibert et al., 1985; Laws, 1984). The high tracer additions can result in stimulation of the phytoplankton growth and artificially high uptake rates. Rates corrected for high tracer additions were obtained from the model by Eppley et al. (1977) and compared with the rates presented here. There were no significant differences between the two data sets (data not shown). As mentioned above, the isotopic dilution of the tracer for both ammonium (Glibert et al., 1982) and nitrate (Ward et al., 1989; Clark et al., 2007) might lead to underestimates of the uptake rates. Furthermore, if regeneration rates are high, it might also lead to a situation where isotopic equilibrium is reached, i.e. equal isotopic enrichment in the particulate matter (phytoplankton cells) and in the aqueous pool (Glibert et al., 1985). The effect of isotopic dilution can be estimated using the model by Kanda et al. (1987). This again did not show significant differences (see Supplement).

To reiterate, the $f$ ratio is not discussed in this paper due to the number of limitations associated with this proxy. These include the conceptual limitations such as the assumption about nitrification and nitrogen fixation as well as the acknowledged gaps in the measurements (lack of urea uptake, nitrogen regeneration rates, high enrichment in some cases). Instead, the paper focuses on a mechanistic understanding of the factors controlling nitrate and ammonium uptake rates. Corrections by Kanda et al. (1987) and Eppley et al. (1977) changed the nitrogen uptake rates linearly and as such do not affect the final statistical analyses. The simple model for estimating nitrogen uptake rates was therefore preferred.

\subsubsection{Uptake rates for the winter cruise}

For the winter cruise, the specific nitrate uptake rates, $v_{\mathrm{NO}_{3}}$, ranged between 0.002 and $0.107 \mathrm{~d}^{-1}\left(\right.$ mean $\left.=0.017 \mathrm{~d}^{-1}\right)$ at the $55 \%$ light depth. At the $1 \%$ light depth, the specific nitrate uptake ranged between 0.003 and $0.034 \mathrm{~d}^{-1}$ $\left(\right.$ mean $\left.=0.009 \mathrm{~d}^{-1}\right)$. However, when excluding station $15 \mathrm{~N}-1$, located in the subtropical zone, the mean was $0.007 \mathrm{~d}^{-1}$. Specific ammonium uptake rates, $v_{\mathrm{NH}_{4}}$, averaged $0.073(0.006-0.376) \mathrm{d}^{-1}$ for the $55 \%$ light depth and $0.085(0.0004-0.416) \mathrm{d}^{-1}$ for the $1 \%$ light depth.

The absolute nitrate uptake rates, $\rho_{\mathrm{NO}_{3}}$ averaged $8.89(1.28-57.00) \mathrm{nmol} \mathrm{L}^{-1} \mathrm{~d}^{-1}$ and absolute ammonium uptake rates, $\rho_{\mathrm{NH}_{4}}, 31.91(2.31-158.05) \mathrm{nmolL}^{-1} \mathrm{~d}^{-1}$ at $55 \%$ sPAR. At the $1 \%$ light depth, the average $\rho_{\mathrm{NO}_{3}}$ was $5.98(1.07-35.98) \mathrm{nmolL}^{-1} \mathrm{~d}^{-1}$. When excluding station $15 \mathrm{~N}-1$, the average $\rho_{\mathrm{NO}_{3}}$ was $3.25(1.07-8.95) \mathrm{nmolL}^{-1} \mathrm{~d}^{-1}$. The average $\rho_{\mathrm{NH}_{4}}$ at the $1 \%$ light depth was $35.44(0.17-$ 160.94) nmol L ${ }^{-1} \mathrm{~d}^{-1}$.

In this data set, the $55 \%$ light depth nitrate uptake rate at station $15 \mathrm{~N}-6$ was much higher than other nitrate uptake rates in the Antarctic zone. It was also much higher than the corresponding nitrate uptake rate at the $1 \%$ light depth. It is considered as an outlier for further statistical analyses as it exceeds the mean by more than 2 standard deviations. On the other hand, the ammonium uptake rates for station $15 \mathrm{~N}-$ 1 were not excluded as they might have been much higher than the average ammonium uptake rate in the data set due the geographical position of this station as well as the higher ammonium concentrations observed at this station.

Table 1 shows the integrated nitrate uptake rates over the mixed layer for the CTD stations from the winter cruise. Integrated $\rho_{\mathrm{NO}_{3}}$ ranged from 0.17 to 
Table 1. Winter depth-integrated $\rho_{\mathrm{NH}_{4}}$, and $\rho_{\mathrm{NO}_{3}}$ and associated SST, MLD (mixed layer depth), $\left[\mathrm{NO}_{3}\right],\left[\mathrm{NH}_{4}\right]$. [ $\left.\mathrm{NO}_{3}\right]$ and $\left[\mathrm{NH}_{4}\right]$ are given for the $55 \%$ light depth only. The detection limit $(\mathrm{dl})$ for $\left[\mathrm{NH}_{4}\right]$ was $0.03 \mu \mathrm{molL} \mathrm{L}^{-1}$. The zones are the frontal zones defined by the criteria of Orsi et al. (1995). STZ represents the subtropical zone, SAZ the subantarctic zone, PFZ the polar frontal zone and AZ the Antarctic zone.

\begin{tabular}{|c|c|c|c|c|c|c|c|c|}
\hline \multirow[b]{2}{*}{$\begin{array}{l}\text { Station } \\
\text { number }\end{array}$} & \multirow[b]{2}{*}{ Zone } & \multirow[b]{2}{*}{$\begin{array}{r}\text { SST } \\
{ }^{\circ} \mathrm{C}\end{array}$} & \multirow[b]{2}{*}{$\begin{array}{r}\text { MLD } \\
\mathrm{m}\end{array}$} & \multirow[b]{2}{*}{$\begin{array}{r}{\left[\mathrm{NH}_{4}\right]} \\
\mu \mathrm{molNL}{ }^{-1}\end{array}$} & \multirow[b]{2}{*}{$\begin{array}{r}{\left[\mathrm{NO}_{3}\right]} \\
\mu \mathrm{molNL} \mathrm{NL}^{-1}\end{array}$} & \multicolumn{3}{|c|}{ Depth integrated } \\
\hline & & & & & & $\begin{array}{l}\text { Chlorophyll } \\
\mathrm{mg} \mathrm{m}^{-2}\end{array}$ & $\operatorname{mmolN~m}^{-2} \mathrm{~d}^{\rho_{\mathrm{NH}_{4}}}$ & $\mathrm{mmolNm}^{-2}{\stackrel{\mathrm{NO}_{3}}{\mathrm{~d}^{-1}}}^{-1}$ \\
\hline $15 \mathrm{~N}-2$ & STZ & 15 & 236 & 0.25 & 3.15 & 33.22 & 13.12 & 1.02 \\
\hline $15 \mathrm{~N}-3$ & SAZ & 10 & 206 & 1.7 & 9.30 & 33.09 & 32.86 & 0.34 \\
\hline $15 \mathrm{~N}-4$ & PFZ & 6.9 & 200 & 0.06 & 16.57 & 22.30 & 1.70 & 1.31 \\
\hline $15 \mathrm{~N}-5$ & PFZ & 5.4 & 151 & 0.35 & 18.18 & 30.78 & 8.32 & 0.61 \\
\hline $15 \mathrm{~N}-6$ & $\mathrm{AZ}$ & 2 & 178 & 0.19 & 22.90 & 22.73 & 0.60 & 5.20 \\
\hline $15 \mathrm{~N}-7$ & AZ & 0.9 & 142 & 0.1 & 28.46 & 17.40 & 1.70 & 0.22 \\
\hline $15 \mathrm{~N}-8$ & $\mathrm{AZ}$ & -1 & 126 & 0.46 & 25.57 & 13.22 & 2.13 & 0.45 \\
\hline $15 \mathrm{~N}-11$ & $\mathrm{AZ}$ & 0.4 & 165 & 1.8 & 20.00 & 18.57 & 8.03 & 0.21 \\
\hline $15 \mathrm{~N}-13$ & PFZ & 5.4 & 59 & 0.07 & 16.44 & 12.95 & 0.81 & 0.17 \\
\hline $15 \mathrm{~N}-15$ & PFZ & 5 & 180 & below $\mathrm{dl}$ & 16.06 & 19.91 & 2.00 & 0.57 \\
\hline $15 \mathrm{~N}-16$ & PFZ & 5.4 & 206 & below $\mathrm{dl}$ & 16.66 & 24.79 & 2.73 & 2.46 \\
\hline
\end{tabular}

$5.20 \mathrm{mmol} \mathrm{m}^{-2} \mathrm{~d}^{-1}\left(\right.$ mean $\left.=1.14 \mathrm{mmol} \mathrm{m}^{-2} \mathrm{~d}^{-1}\right)$ and integrated ammonium uptake from 0.60 to $32.86 \mathrm{mmol} \mathrm{m}^{-2} \mathrm{~d}^{-1}$ $\left(\right.$ mean $\left.=6.73 \mathrm{mmol} \mathrm{m}^{-2} \mathrm{~d}^{-1}\right)$.

\subsubsection{Uptake rates for the summer cruise}

For the summer cruise, more detailed depth profiles were available (Fig. 3). The uptake rates are shown as an hourly average rate as the incubations lasted $12 \mathrm{~h}$. CTDs 1 and 2 were the two CTD stations outside the subantarctic zone and process study. They showed similar nitrate uptake profiles (Fig. 3a). CTD 2 (which was further north) however has lower subsurface nitrate uptake rates than CTD 1. At process station A (Fig. 3c), nitrate uptake increased between the CTD stations conducted on 25 February 2013 (CTD 4) and 5 March 2013 (CTD 14). Between CTD 14 and 15, there was a change in the nitrate uptake pattern. CTD 4, 8 and 14 all showed a subsurface maximum in terms of nitrate uptake. This maximum value was found at the $10 \%$ light depth for CTD 4 and 14 but was shallower at CTD 8. For CTD 15, the nitrate uptake rate at $20 \mathrm{~m}(30 \%$ light depth) represented a minimum rate. This rate then surprisingly increased with depth to the $1 \%$ light level.

At process station B (Fig. 3e), two of the stations (CTD 7 and 9) showed nitrate uptake rates which decreased with depth. Differences between CTD 7 and 9 were minimal. At the $55 \%$ light depth, nitrate uptake for CTD 13 was very similar to the two other stations. However, nitrate uptake rates at this station were much larger subsurface, with a maximum at $20 \mathrm{~m}$. At process station A, three ammonium uptake profiles were available (Fig. 3d). For CTD 4 and 14, ammonium uptake decreased with depth. At CTD 15, however, ammonium uptake increased with depth. Those patterns were opposite to the nitrate uptake pattern. At process station B, ammonium uptake rates were only available for a few points
(Fig. 3f). CTD 7 showed a greater ammonium uptake rate than CTD 9 and 13 at the $60 \mathrm{~m}$ depth $(0.3 \%$ light depth). For CTD 13, like the nitrate uptake, ammonium uptake was maximum at $20 \mathrm{~m}$. As expected, the subsurface maximum in chlorophyll at CTD 14 coincided with the maximum uptake rate. At CTD 4 and 8, the subsurface minimum of chlorophyll was at the subsurface maximum of nitrate uptake.

The integrated summer uptake rates are shown in Table 2. During the summer cruise, the mean-integrated nitrate uptake rate was $0.20 \mathrm{mmolNm}^{-2} \mathrm{~d}^{-1}$ with a range between 0.10 and $0.38 \mathrm{mmol} \mathrm{N} \mathrm{m}^{-2} \mathrm{~d}^{-1}$. The integrated ammonium uptake rate averaged $4.39 \mathrm{mmol} \mathrm{N} \mathrm{m}^{-2} \mathrm{~d}^{-1}$ and ranged from 1.12 to $9.05 \mathrm{mmol} \mathrm{N} \mathrm{m}^{-2} \mathrm{~d}^{-1}$.

\subsection{Biogeochemical controls on nitrogen uptake}

\subsubsection{Winter cruise}

A multivariate statistical analysis was performed to determine which one of the environmental variables (nitrate, nitrite and ammonium concentrations, day length, SST and MLD) had the most influence on nitrate and ammonium uptake by phytoplankton.

The first step was a cluster analysis. The hypothesis tested here was whether clusters based on the uptake rates are separated by the subtropical, subantarctic and polar fronts. Two cluster analyses were undertaken one based on the environmental variables at the 55 and $1 \%$ light depths and the other on the uptake rates. The environmental clustering showed clusters which were separated by the fronts. This was an expected result as the location of the fronts and the delineation of the different regions (subtropical, subantarctic, polar frontal and Antarctic zones) is based on environmental parameters. In the cluster analysis based on the uptake rates, stations did not follow such clear cut separation across the 

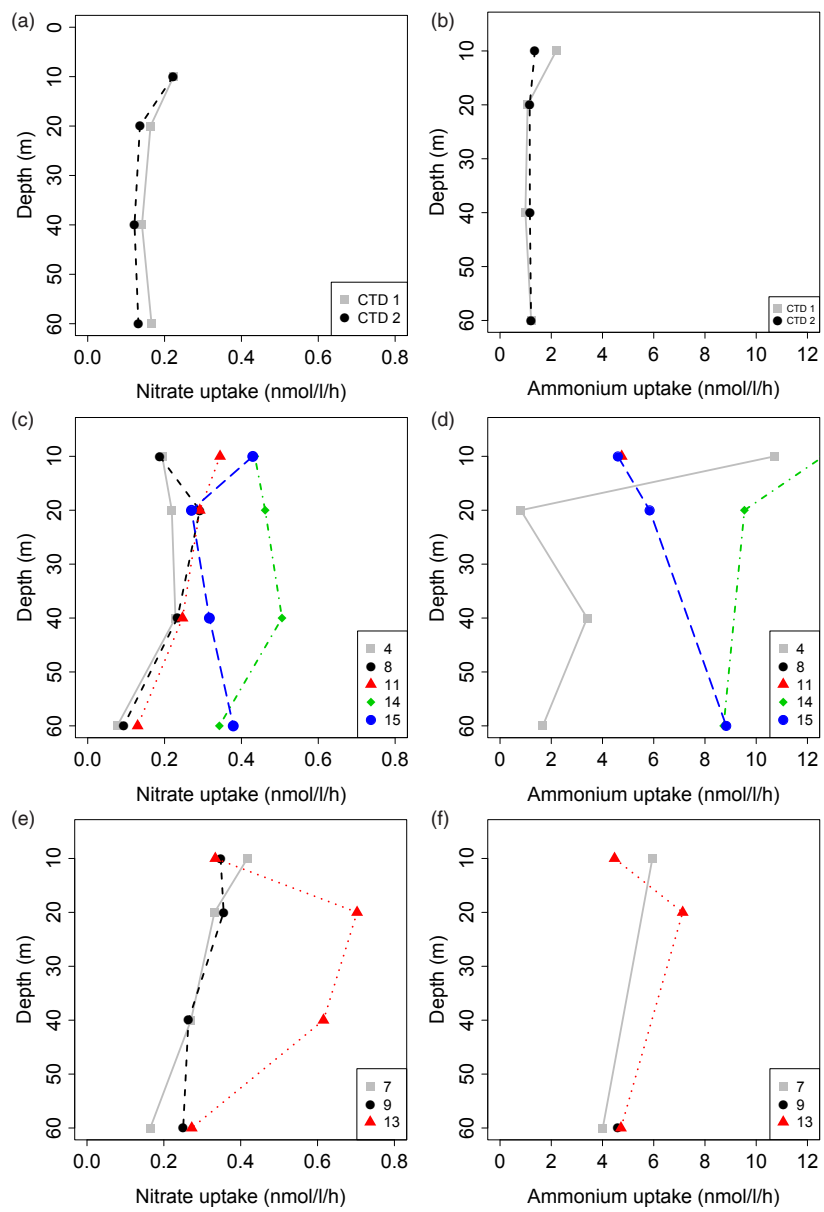

Figure 3. Nitrate and ammonium uptake rates profiles for the summer cruise; (a), (c) and (e) show the nitrate uptake profiles for the polar frontal zone stations, process station A and B; (b), (d) and (f) show the ammonium uptake profiles for the polar frontal zone stations, process station $\mathrm{A}$ and $\mathrm{B}$. The numbers in the legend represent the CTD (conductivity-temperature-depth) stations.

fronts. Stations, situated far from each other geographically, had similar responses. For example stations $15 \mathrm{~N}-3$ and $15 \mathrm{~N}-$ 11 were placed in the same cluster. When using only the CTD stations for the cluster analysis, $15 \mathrm{~N}-2$, however, was identified as a subantarctic station rather than a subtropical station where it was actually located. This could be due to its proximity to the subtropical front. While surface parameters at this station were typical of the subtropical front, the transition was not so clear in deeper waters. For the rest of the analysis, $15 \mathrm{~N}-2$ will be considered as a subantarctic station rather than a subtropical one.

A RDA was then performed. The RDA combines a principal component analysis and multiple regressions. The process identifies sets of axes along which most of the variation can be explained. As stated previously, in this analysis, station $15 \mathrm{~N}-6$ was considered as an outlier and not used because it had a very high nitrate uptake rate. On the plot, the angle between the blue lines represent the strength of the correlation between the environmental parameters. Acute angles represent positive correlations whereas obtuse angles represent negative correlations. Stronger positive correlations are shown by smaller angles while a $180^{\circ}$ angle represents a correlation of -1 . A $90^{\circ}$ angle indicates no correlation. The length of the arrows shows the contribution of each environmental variable to the total variance in the responses (uptake rates). The shorter the arrow, the less important the variable is in terms of explaining differences in uptake rates. The angle between the blue arrows and red lines shows the correlation between the environmental parameter and each response variable (Borcard et al., 2011).

The controlling factors included in the analysis were the day length and MLD as measures of light limitation, SST and nutrient concentrations $\left(\left[\mathrm{NO}_{3}^{-}\right],\left[\mathrm{NH}_{4}^{+}\right],\left[\mathrm{NO}_{2}^{-}\right]\right)$. The $\mathrm{Si}(\mathrm{OH})_{4}$ and $\mathrm{PO}_{4}^{3-}$ were not included in the analysis as they are strongly colinear with the $\mathrm{NO}_{3}^{-}$concentrations. Such strong colinearity results in additional variation which is insignificant. While SST and day length were also strongly correlated, they were included in the analysis in order to determine which of the two factors has a larger influence on the uptake rates.

The RDA plot is shown in Fig. 4. The angle between the arrow representing day length and nitrate uptake was smaller than between SST and nitrate uptake. This implies that day length had a more important role in the regulation of nitrate uptake than SST. Ammonium concentration was positively correlated to ammonium uptake and negatively correlated to nitrate uptake. Though the MLD was negatively correlated to nitrate uptake, the length of its representative arrow indicates that it did not contribute significantly to the variation in the uptake rates. Similar results were obtained with an RDA which included all the underway stations and the specific uptake rates and excluded the MLD. The unadjusted and adjusted $R^{2}$ values for the RDA were 0.74 and 0.36 respectively. This gives an indication of the proportion of variance that can be explained through this analysis. A permutation test confirmed ( $p$ value $=0.0967$ ) that the RDA was significant and that the relationship between the environmental parameters and uptake rates was not random. Given this information, it was possible to perform a forward selection of variables (Borcard et al., 2011), which allows an identification of the minimum number of environmental variables explaining the maximum variation in the response variables (uptake rates). This process identified day length and ammonium concentration as the two variables which influenced the variation in uptake rates the most. The controlling factors in this RDA explain $36 \%$ (adjusted $R^{2}$ ) of the variation in the uptake rates. This value has to be adjusted as the RDA employs multiple regressions. Each regression is a hypothesis test. At each iteration, the probability of making a type I error (where a relationship that is not significant is seen as significant) increases and this needs to be accounted for. The algo- 
Table 2. Summer depth-integrated $\rho_{\mathrm{NH}_{4}}, \rho_{\mathrm{NO}_{3}}$ and chlorophyll concentration and associated SST, MLD (mixed layer depth), [NH 4 and $\left[\mathrm{NO}_{3}\right] .\left[\mathrm{NO}_{3}\right]$ and $\left[\mathrm{NH}_{4}\right]$ are given for the $55 \%$ light depth only.

\begin{tabular}{|c|c|c|c|c|c|c|c|c|c|c|}
\hline \multirow{2}{*}{$\begin{array}{c}\text { Process } \\
\text { station } \\
-\end{array}$} & \multirow[b]{2}{*}{$\begin{array}{l}\text { Date } \\
-\end{array}$} & \multirow[b]{2}{*}{$\begin{array}{l}\text { Lat } \\
{ }^{\circ} \mathrm{N}\end{array}$} & \multirow[b]{2}{*}{$\begin{array}{l}\text { Long } \\
{ }^{\circ} \mathrm{E}\end{array}$} & \multirow[b]{2}{*}{$\begin{array}{c}{\left[\mathrm{NH}_{4}\right]} \\
\mu \mathrm{molNL}{ }^{-1}\end{array}$} & \multirow[b]{2}{*}{$\begin{array}{c}{\left[\mathrm{NO}_{3}\right]} \\
\mu \mathrm{molNL}^{-1}\end{array}$} & \multirow[b]{2}{*}{$\begin{array}{c}\mathrm{SST} \\
{ }^{\circ} \mathrm{C}\end{array}$} & \multirow[b]{2}{*}{$\begin{array}{c}\text { MLD } \\
\mathrm{m}\end{array}$} & \multicolumn{3}{|c|}{ Depth integrated } \\
\hline & & & & & & & & $\begin{array}{c}\text { chlorophyll } \\
\mathrm{mg} \mathrm{m}^{-2}\end{array}$ & $\begin{array}{c}\rho_{\mathrm{NH}_{4}} \\
\mathrm{mmolNm}\end{array}$ & $\begin{array}{c}\rho_{\mathrm{NO}_{3}} \\
\mathrm{mmolNm}\end{array}$ \\
\hline A & 26 Feb 2013 & -42.645 & 8.6867 & 0.05 & 6.65 & 12.19 & 57 & 40.07 & 2.86 & 0.13 \\
\hline A & 1 Mar 2013 & -42.7412 & 8.8111 & & 9.29 & 11.27 & 54 & 25.95 & & \\
\hline A & 3 Mar 2013 & -42.7758 & 9.1892 & 0.31 & 9.01 & 11.23 & 37 & 16.77 & & 0.17 \\
\hline A & 5 Mar 2013 & -42.6436 & 9.4306 & 0.93 & 13.05 & 10.72 & 69 & 31.69 & 9.05 & 0.32 \\
\hline A & 7 Mar 2013 & -42.6153 & 9.5967 & 0.34 & 12.69 & 10.28 & 76 & 32.29 & 6.57 & 0.23 \\
\hline B & 28 Feb 2013 & -43.5064 & 7.1858 & 0.30 & 13.09 & 9.96 & 65 & 34.69 & & 0.20 \\
\hline B & 2 Mar 2013 & -43.4233 & 7.1785 & & 12.93 & 10.02 & 82 & 31.35 & & 0.21 \\
\hline B & 4 Mar 2013 & -43.5178 & 7.1315 & 0.41 & 12.47 & 10.03 & 85 & 33.49 & 5.60 & 0.38 \\
\hline
\end{tabular}

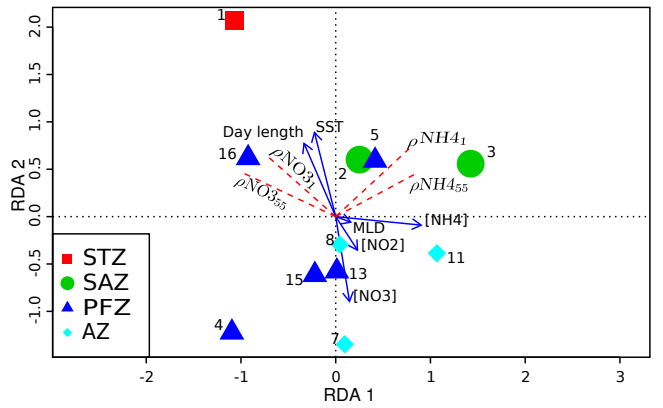

Figure 4. RDA triplot. The blue arrows represent the environmental parameters. The red dashed lines are the response variables. The stations are labelled based on the zone in which they are located. $\rho \mathrm{NO}_{31}$ and $\rho \mathrm{NO}_{355}$ represent $\rho_{\mathrm{NO}_{3}}$ at the 1 and $55 \%$ light depths, respectively, and $\rho \mathrm{NH}_{41}$ and $\rho \mathrm{NH}_{455}$ the $\rho_{\mathrm{NH}_{4}}$ at the same light depths. The uptake rates were log-transformed. SST is the seasurface temperature, $\left[\mathrm{NO}_{2}\right],\left[\mathrm{NO}_{3}\right]$ and $\left[\mathrm{NH}_{4}\right]$ the concentrations of nitrite, nitrate and ammonium. The numbers for each station are the $15 \mathrm{~N}$ station numbers. The numbers in the legend represent the CTD (conductivity-temperature-depth) stations.

rithm used here has been shown to be conservative (Borcard et al., 2011). This would mean that the parameters used here explain more that $36 \%$ of the variation in nitrogen uptake.

\subsubsection{Summer cruise}

A correlation matrix was performed for the summer cruise (Table 3). Associated $p$ values are also shown. It is to be noted that due to the limited number of observations, these $p$ values have not been adjusted. While these correlations can give an indication of important processes, the statistical significance is to be taken with caution. As the mixed layer depth increased, SST decreased as shown by the strong negative correlation between the two parameters. This also corresponded to an increase in the concentration of nitrate, nitrite, ammonium and phosphate concentrations. Silicate concentration was the only nutrient concentration to decrease with deeper vertical mixing. Both ammonium and nitrate uptake increased when the mixed layers were deeper even though the chlorophyll concentrations decreased.

\section{Discussion}

\subsection{Comparison of nitrogen uptake rates with previous studies}

Shipboard observations allow for a snapshot view of nitrogen uptake. In order to obtain a more complete image of the seasonal and interannual variability, a comparison with historical data is useful. Figures 5 and 6 compare the absolute nitrate and ammonium uptake rates for the two cruises with historical data. The historical data include data along the GoodHope line (Joubert et al., 2011), the Indian sector (Thomalla et al., 2011b) and data collected during three South African National Antarctic Expedition (SANAE) cruises. SANAE cruises are yearly cruises which take place between December and February in the Atlantic sector of the Southern Ocean. The data and cruise reports for the SANAE cruises are available from the Greenseas database (http://greenport. nersc.no). These data were either results from $24 \mathrm{~h} 15 \mathrm{~N}$ incubations or presented as daily rates. The hourly summer uptake rates have therefore been converted to a daily rate to allow for comparison. As described in Sect. 2.1, the hourly nitrate uptake rate was multiplied by the light period and the hourly ammonium uptake by the light period plus half of the dark period. The light period was taken as $14 \mathrm{~h}$.

The nitrogen uptake rates shown in Figs. 5 and 6 span several orders of magnitude and show large variability even within single studies. It is to be noted that the geographical ranges of these studies was very wide. In terms of longitudes, the stations ranged from -36.41 to $44.27^{\circ} \mathrm{E}$. Given the large spatial differences, the phytoplankton community structure as well as the biogeochemical settings vary significantly and result in large differences in nitrogen uptake rates (Boyd et al., 2010).

Winter uptake rates from previous winter and autumn studies (Cota et al., 1992; Smith Jr. and Nelson, 1990) are com- 


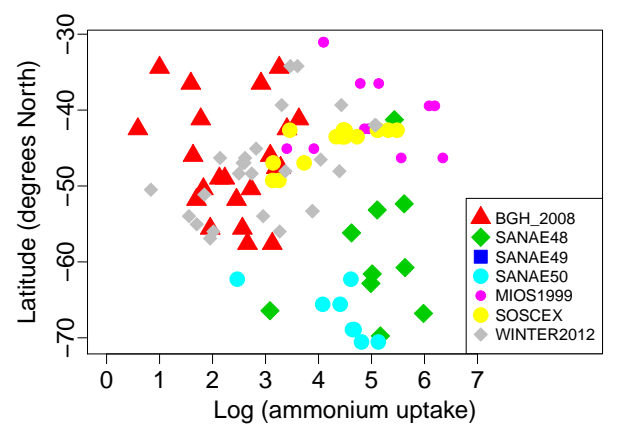

Figure 5. Comparison of ammonium uptake rates from the summer cruise (SOSCEx) and the winter cruise (WINTER2012) and previous cruises. $\log p_{\mathrm{NH}_{4}}$ (in nmol $\mathrm{L}^{-1} \mathrm{~d}^{-1}$ ) is shown here for clarity. The data include both the 55 and $1 \%$ light depths where available for each cruise. The summer uptake rates (SOSCEx) were converted to daily rates by multiplying the average hourly rate by the light period + half of the dark period. The data shown here include data from Joubert et al. (2011) (BGH2008), the SANAE cruises in 2009, 2010 and 2011 (SANAE48,49,50) and Thomalla et al. (2011b) (MIOS1999). The data and cruise reports for the SANAE cruises are available from the Greenseas database (http://greenport.nersc.no).

parable with the current data set (see Supplement). As expected, $\rho_{\mathrm{NO}_{3}}, v_{\mathrm{NO}_{3}}$ and therefore $\int \rho_{\mathrm{NO}_{3}}$ were lower in winter than in summer and spring. The extent of the seasonal difference varied from region to region. In the subtropical zone, nitrogen uptake rates were of similar order of magnitude for both seasons (Thomalla et al., 2011b). Further south, the differences between summer and winter rates increased; winter $\rho_{\mathrm{NO}_{3}}$ along the GoodHope line were between 2 and 80 times smaller than summer rates measured by Joubert et al. (2011) for similar latitudes and light depths.

The summer nitrate uptake rates presented here were lower than summer rates from most past studies (Fig. 6 and Supplement). The nitrate uptake rates from the summer cruise were, indeed, very similar to the winter uptake rates (Fig. 6). Most of the summer studies were conducted between December and February. For instance, integrated nitrate uptake in the subantarctic zone (SAZ) from Savoye et al. (2004) were greater than our estimates. While this could be due to longitudinal variations, it is to be noted that the sampling by Savoye et al. (2004) was done in October and December. At that point, it is likely that the phytoplankton were not yet affected by nutrient limitations (e.g. iron). While Joubert et al. (2011) sampled at a similar time of the year, their high nitrate uptake rates for subantarctic zone stations were due to an anticyclonic eddy in this region at the time of sampling. For Gandhi et al. (2012), sampling extended from December to April and the nitrate concentrations and uptake rates were comparable to the summer uptake in this data set.

The variations in nitrate uptake are in contrast with ammonium uptake rates which did not vary much seasonally or geographically (Fig. 5). The ammonium uptake for the winter cruise was very weakly correlated to latitude. Rates from

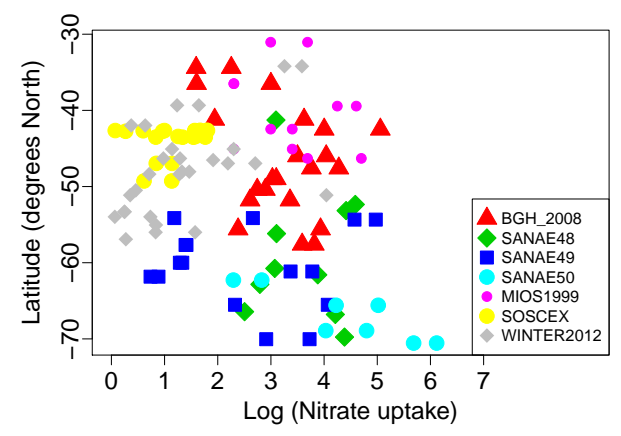

Figure 6. Comparison of nitrate uptake rates from the summer cruise (SOSCEx) and the winter cruise (WINTER2012) and previous cruises. $\log p_{\mathrm{NO}_{3}}$ (in $n m o l L^{-1} \mathrm{~d}^{-1}$ ) is shown here for clarity. The data include both the $55 \%$ and $1 \%$ light depths where available for each cruise. The summer uptake rates (SOSCEx) were converted to daily rates by multiplying the average hourly rate by the light period. The data shown here include data from Joubert et al. (2011) (BGH2008), the SANAE cruises in 2009, 2010 and 2011 (SANAE48,49,50) and Thomalla et al. (2011b) (MIOS1999). The data and cruise reports for the SANAE cruises are available from the Greenseas database (http://greenport.nersc.no).

the winter and summer cruises were similar to previous studies. A preference for ammonium was observed during the two cruises. Both $v_{\mathrm{NH}_{4}}$ and $\rho_{\mathrm{NH}_{4}}$ were higher than $v_{\mathrm{NO}_{3}}$ and $\rho_{\mathrm{NO}_{3}}$ respectively. Such a preference has been observed in winter (Cota et al., 1992), summer (Semeneh et al., 1998b) and autumn (Thomalla et al., 2011b).

There are instances, however, where nitrate uptake is preferred (Waldron et al., 1995; Gandhi et al., 2012; Sambrotto and Mace, 2000; Smith Jr. and Nelson, 1990). Gandhi et al. (2012) measured higher nitrate uptake than ammonium and urea uptakes during the summer on transects in the Indian sector of the Southern Ocean. Sambrotto and Mace (2000) observed a shift in preference from nitrate to ammonium between December and February in the Pacific sector of Southern Ocean. Waldron et al. (1995) reported a preference for nitrate within a pelagic bloom. This preference decreased southwards as stations closer to the ice edge were sampled. Smith Jr. and Nelson (1990) also observed a preference for nitrate. However, in the study by Smith Jr. and Nelson (1990), as the season progressed from spring into autumn, there was no shift in preferential uptake but a decrease in both uptake rates. Unavailability of nitrate or silicic acid as well as changes within the phytoplankton community structure can lead to a preference for regenerated nutrients. The smaller (seasonal and geographical) variation in $\mathrm{NH}_{4}^{+}$uptake are due to the lower energy requirements of $\mathrm{NH}_{4}^{+}$uptake compared to $\mathrm{NO}_{3}^{-}$uptake. The phytoplankton are able to use $\mathrm{NH}_{4}^{+}$even under severe limitations such as low light in winter and decreased nutrients in summer. 
Table 3. Spearman correlation matrix of uptake rates and environmental variables for the summer cruise with the associated $p$ values. $v_{\mathrm{NH}_{4}}$ and $v_{\mathrm{NO}_{3}}$ are the specific ammonium and nitrate uptake rates while $\rho_{\mathrm{NH}_{4}}$ and $v_{\mathrm{NO}_{3}}$ are the absolute uptake rates. SST is the seasurface temperature and MLD (mixed layer depth) the mixed layer depth. $\left[\mathrm{NH}_{4}^{+}\right],\left[\mathrm{NO}_{3}^{-}\right],\left[\mathrm{NO}_{2}^{-}\right],\left[\mathrm{Si}(\mathrm{OH})_{4}\right],\left[\mathrm{PO} 4^{3-}\right]$ and $[\mathrm{Chl}]$ are the concentrations of ammonium, nitrate, nitrite, silicic acid, phosphate and chlorophyll.

\begin{tabular}{crrrrrrrr}
\hline & $v_{\mathrm{NH}_{4}}$ & $p$ value & $\rho_{\mathrm{NH}_{4}}$ & $p$ value & $v_{\mathrm{NO}_{3}}$ & $p$ value & $\rho_{\mathrm{NO}_{3}}$ & $p$ value \\
\hline $\mathrm{SST}$ & -0.23 & 0.43 & -0.13 & 0.67 & -0.66 & 0.01 & -0.47 & 0.09 \\
{$\left[\mathrm{NH}_{4}^{+}\right]$} & 0.66 & 0.01 & 0.54 & 0.05 & 0.62 & 0.02 & 0.5 & 0.07 \\
{$\left[\mathrm{NO}_{3}^{-}\right]$} & 0.32 & 0.27 & 0.42 & 0.13 & 0.56 & 0.04 & 0.57 & 0.03 \\
{$\left[\mathrm{NO}_{2}^{-}\right]$} & 0.37 & 0.19 & 0.35 & 0.22 & 0.56 & 0.04 & 0.29 & 0.32 \\
{$\left[\mathrm{Si}(\mathrm{OH})_{4}\right]$} & -0.4 & 0.15 & -0.46 & 0.09 & -0.31 & 0.28 & -0.27 & 0.36 \\
{$\left[\mathrm{PO}_{4}^{3-}\right]$} & 0.25 & 0.38 & 0.23 & 0.44 & 0.46 & 0.1 & 0.41 & 0.15 \\
{$[\mathrm{Chl}]$} & 0.16 & 0.59 & 0.33 & 0.25 & -0.19 & 0.52 & -0.05 & 0.86 \\
$\mathrm{MLD}$ & 0.36 & 0.21 & 0.29 & 0.31 & 0.73 & 0 & 0.62 & 0.02 \\
\hline
\end{tabular}

\subsection{Biogeochemical controls on nitrogen uptake}

Given the importance of nitrogen uptake and its links to the global carbon and nitrogen cycle, it is important to understand the factors which control these processes. This section discusses various controls on nitrogen uptake for the winter and summer seasons. This was investigated using multivariate statistical analyses (Sects. 2.2 and 3.3).

\subsubsection{The fronts}

Two cluster analyses (one on the environmental variables, the other on the uptake rates) were undertaken on the winter data to test the hypothesis that the location of the stations relative to the fronts regulated the nitrogen uptake regime. The cluster analysis for the environmental parameters corresponded to the fronts. This was to be expected as the fronts separate waters with different environmental properties. Stations with similar nitrogen uptake regimes, however, were not separated based on their positions relative to the fronts. This shows that the frontal positions cannot be used to distinguish between nitrogen uptake regimes, especially in winter, and that the factors controlling nitrogen uptake are not a simple linear combination of the various environmental variables.

\subsubsection{Temperature}

Temperature is expected to have the same effect on nitrogen uptake by phytoplankton as on photosynthesis. In some cases, the growth rate is halved for every drop of $10^{\circ} \mathrm{C}$ (Smith Jr. and Harrison, 1991; Tilzer and Dubinsky, 1987). Positive correlations have been observed between nitrate uptake and phytoplankton growth and temperature in the Southern Ocean (Smith Jr. and Harrison, 1991; Reay et al., 2001). At temperatures above $0{ }^{\circ} \mathrm{C}$, this relationship was no different to that of temperate phytoplankton and temperature (Smith Jr. and Harrison, 1991). Polar phytoplankton do not seem to have special adaptations to the low temperatures which they encounter in their natural environment (Smith Jr. and Harrison, 1991; Reay et al., 2001; Cochlan, 2008). At low temperatures, nitrate uptake rates are potentially limited by its transport into the cell rather than assimilation rates (Reay et al., 2001; Lomas and Glibert, 1999; Cochlan, 2008), however, the effect of temperature on polar assemblages is not completely understood as a number of culture studies have been done at temperatures which are much higher than the natural ambient temperatures (Cochlan, 2008).

In agreement with previous studies, a positive correlation was shown between temperature and nitrogen uptake during the winter cruise. However, the RDA for the winter cruise showed that the general decrease in $\rho_{\mathrm{NO}_{3}}$ and $v_{\mathrm{NO}_{3}}$ with latitude, temperature and day length during the winter cruise was more strongly correlated to day length than temperature. This is in line with differences reported between summer and winter rates. When considering summer rates from previous studies, the temperature differences are not large enough to explain the variations in the uptake rates. Furthermore, within the subantarctic zone, temperatures were higher during the summer cruise than the winter one. Nitrogen uptake rates on the other hand were very similar. During the summer cruise nitrate uptake increased when temperature decreased (Table 3). This is in agreement with the model developed by Laws et al. (2000). In nutrient limited regions, low temperatures were linked to vertical mixing, which lead to nutrient inputs and enhanced primary production. During the summer cruise, the decreases in temperature corresponded to mixing events and increases in nutrient uptake rates.

As it has been reported for previous studies (Reay et al., 2001; Laws et al., 2000), the correlation between nitrate uptake and temperature was stronger than that between ammonium uptake and temperature during both cruises. The low dependency of ammonium uptake on temperature and the contradictory responses of nitrate uptake to temperature for the summer and winter cruises show that temperature alone cannot explain variations in the nitrogen uptake regimes. Other factors, such as light and nutrient availability, might have more impact through their interactions with 
each other and with temperature (Tilzer and Dubinsky, 1987; Reay et al., 2001).

\subsubsection{Irradiance}

The current data set supports the use of light availability as one of the main drivers of nitrate uptake during the winter (Boyd, 2002; Boyd et al., 2010) but not for ammonium uptake. The amount of light available to phytoplankton is controlled by the time of the year (effectively day length) and the mixed layer depth (Smith Jr. and Harrison, 1991; Cochlan, 2008). The relationship between nitrogen uptake rates and light is similar to that of nitrogen uptake rates and inorganic nitrogen concentrations. Increasing light (or nutrients) will result in increasing phytoplankton growth up to the point of process saturation. At this maximal growth rate, the system is said to be saturated (Smith Jr. and Harrison, 1991; Cochlan, 2008). However, there are contradictions to this simple relationship. Maximal rates can be found at depths with 1 and even $0.1 \%$ of the surface irradiance (Cochlan, 2008). For instance, subsurface maxima were observed in several of the nitrate uptake profiles (CTDs 4, 8, 13, 14) while at the summer process station $\mathrm{A}$, one of the nitrate uptake profiles (CTD 15) showed higher nitrate uptake at $60 \mathrm{~m}$ rather than at $20 \mathrm{~m}$. For the winter cruise, similar uptake rates were observed in samples incubated at simulated 55 and $1 \%$ light depths. The relationship between irradiance and nitrogen uptake by phytoplankton can also be influenced by a number of other factors such as the bloom stage and phytoplankton community structure (Smith Jr. and Harrison, 1991; Cochlan, 2008).

The use of the mixed layer depth as a determining factor for phytoplankton growth (Sverdrup, 1953) has been a classic tenet of biological oceanography. It assumes that a phytoplankton bloom is not possible if the depth of vertical mixing is deeper than the critical depth. At the critical depth, losses through respiration and other processes exceed growth from photosynthesis. Moreover, with deep vertical mixing, phytoplankton are not exposed to light for long enough to allow nutrient uptake. Consequently, growth would slow down (Mitchell et al., 1991).

The winter data show a negative correlation with the nitrate uptake as expected (as MLD decreases, nitrate uptake increases) but not with ammonium uptake. However, the MLD appears to play a limited role. The length of each arrow (representing a variable) on the RDA plot indicates its relative contribution to explaining the variability of the data set. The MLD arrow here was very short. It is possible that changes in MLD during the days preceding sampling have a more important effect than the MLD at the time of sampling. The effect of vertical mixing is not always instantaneous. For instance, Venables et al. (2013) have shown that the depth of mixed layer during winter on the western Antarctic Peninsula could influence phytoplankton growth during the following summer. Furthermore, they also showed that at the time of sampling, incoming irradiance - a function of day length - was a more important control than MLD. This is because the critical depth depends on incoming irradiance - the higher the incoming irradiance, the deeper the critical depth. This is also seen in the winter data set where day length was very strongly correlated to nitrate uptake. Day length was also one of the two factors explaining most of the variation in nitrogen uptake regime during the winter cruise. This is in agreement with the model by Vernet et al. (2012) which showed a strong correlation between the seasonal cycle of day length and primary production close to the Antarctic Peninsula.

Light limitation also changes the responses of phytoplankton to other factors. For example, Tilzer and Dubinsky (1987) showed that the light: dark ratio modulated the responses of phytoplankton to low temperatures. Photosynthesis (dominant in light periods) and respiration (dominant in dark periods) have differential temperature dependencies. Therefore, when temperature changes, the amount of daylight required to maintain a balance between growth from photosynthesis and losses from respiration also changes.

In addition, light limitation can lead to a decoupling of carbon and nitrogen uptake (Smith Jr. and Harrison, 1991). Under low light conditions, nitrogen uptake saturates first leading to an increased $C: N$ ratio. Such increased $C: N$ ratios were not observed in our data set. The $\mathrm{C}: \mathrm{N}$ ratio was on average 6.75 , which is very close to the classic Redfield $\mathrm{C}: \mathrm{N}$ ratio (6.6).

This could be due to the fact that the light periods during the winter cruise, when one would expect light limitation, were still significant. The station furthest south was located at $-56.92^{\circ} \mathrm{N}$ and had a day length of $7.6 \mathrm{~h}$. This is located far from positions where periods of total darkness are experienced much closer to the Antarctic Peninsula (Vernet et al., 2012). During the summer cruise, the day lengths for all stations were very similar and this was therefore not considered as a major factor affecting the variability in uptake rates. Nitrogen uptake rates increased when mixed layer depth increased in contrast with the idea that shallow mixed layers would reduce light limitation and enhance primary production. This shows that the changes in vertical mixing impacts controls other than light availability and that depending on the season or stage of bloom, factors such as nutrient availability might become more important than light.

\subsubsection{Nutrients}

While increased vertical mixing is purported to create unfavourable light conditions for phytoplankton growth, it can promote growth by alleviating nutrient limitations. During the summer cruise, nitrate concentrations at the $55 \%$ light depth ranged between 6.65 and $13.09 \mu \mathrm{molL}^{-1}$ (Table 2). As mentioned above, within the subantarctic zone during this cruise, nitrate uptake, which was very low, increased as vertical mixing increased. The deeper mixed layers re- 
sulted in enhanced nutrient availability and consequently increased nitrate uptake. However, these nitrate concentrations in themselves were not limiting and it is possible that the influx of other nutrients such as iron lead to the enhanced growth. During the winter cruise, surface nitrate concentrations ranged from $1.93 \mu \mathrm{molL}^{-1}$ in the subtropical zone to $27.47 \mu \mathrm{molL}^{-1}$ in the Antarctic zone and were not considered limiting. In addition, there is a negative correlation between nitrate uptake rates and nitrate concentrations. The high nitrate concentrations could be due to low nitrate uptake rates and the inability of the phytoplankton to deplete this nutrient. The high nitrate concentrations were found in the southernmost part of the transect where nitrate uptake could be limited by light availability and temperature. In this section, the importance of iron and ammonium for the nitrogen uptake regime are discussed.

Phytoplankton community structure is strongly influenced by nutrient limitation (Hutchins et al., 2001; Sedwick et al., 2002; Hoffmann et al., 2008). This will not be discussed in detail here as no data on the size or species distribution were available for these two cruises. This lack of data also precludes from an investigation of the links between the $\mathrm{Si}$ and nitrogen cycle. For example, increases in Si can shift the community structure from dinoflagellate dominated to diatom dominated (Hutchins et al., 2001). This would result in changes to the nitrogen uptake regime - the preference for ammonium and other non-nitrate nitrogen sources would probably be reduced.

The role of iron is discussed here in order to assess how the current data fit with iron's well-established role in regulating nitrogen uptake (and primary productivity) within the Southern Ocean (Van Oijen et al., 2004; Strzepek et al., 2012; Sanders et al., 2007; Moore et al., 2007; Falkowski et al., 1998; Cochlan, 2008; Boyd et al., 2010; Boyd, 2002). It is to be noted that these potential effects are purely conjectural as the iron concentrations were not available for the two cruises.

\section{Iron}

In winter, iron limitation by itself is unlikely to be a major control. The deep vertical mixing brings up a constant supply of nutrients (Boyd, 2002; Boyd et al., 2010; Thomalla et al., 2011b). Furthermore, in iron-limited systems, islands can be a source of iron which will enhance primary production and nitrate uptake (Sanders et al., 2007). The stations closer to Marion island would show higher nitrogen uptake than stations further away in the polar frontal zone. This would have been reflected in the cluster analysis as a separate cluster for stations around Marion Island. No such difference was observed. This supports the contention that iron supply was replete at this time of year. Furthermore, during this season, an iron-light co-limitation, in which light might play a more important role than iron, is plausible (Moore et al., 2007; Van Oijen et al., 2004; Strzepek et al., 2012). In autumn, when mixed layers have started deepening and nutrient sup- ply increased, Van Oijen et al. (2004) observed no changes in uptake rates after iron additions. This could either be due to the fact that in autumn, the ambient iron concentrations were sufficient to sustain the phytoplankton community or it could also be linked to interactions between light limitations and iron supply. For instance, Strzepek et al. (2012) found in laboratory experiments that the effects of iron addition on phytoplankton growth were less pronounced under light limitation.

\section{Ammonium}

The RDA plot for the winter data (Fig. 4) show that when ammonium is present, phytoplankton exhibit a preference for this nutrient. Ammonium concentration was identified as one of the factors explaining most of the variance in the data set (Sects. 2.2 and 3.3). The presence of ammonium has two reported effects on the nitrogen uptake regime: it can either inhibit nitrate uptake or increase the specific ammonium uptake rate (Goeyens et al., 1995; Whitehouse et al., 2011; Cochlan, 2008; Smith Jr. and Harrison, 1991). The question remains as to which of the two is more effective at shifting the uptake regime from one which is mainly fuelled by nitrate to one fuelled by regenerated nutrients. Inhibition of nitrate uptake by ammonium has been reported in a number of studies (Goeyens et al., 1995; Smith Jr. and Harrison, 1991; Reay et al., 2001; Semeneh et al., 1998a), but the concentration at which this inhibition effect starts is controversial. Goeyens et al. (1995) synthesised data from nine studies and observed the changes in nitrate depletion and ammonium availability over a full seasonal cycle. Higher ammonium availability was observed when nitrate assimilation decreased. Nitrate assimilation usually decreases after a period of sustained phytoplankton growth. Following such a bloom, the particulate organic matter is re-mineralised to regenerate ammonium (Goeyens et al., 1995). From our winter data, there was no correlation between ammonium and chlorophyll concentrations. There might be a lag between the peak in nitrate uptake and the re-mineralisation of particulate organic matter. In this case, ammonium concentrations would be more likely to correlate with chlorophyll concentrations from some preceding period rather than chlorophyll concentrations at the time of sampling. In the summer data set, a negative correlation was observed between chlorophyll and ammonium concentrations, but this cannot be attributed to an accumulation of ammonium due to re-mineralisation of particulate organic matter. Mixing events during the course of the study could be responsible for entraining the organic matter and bringing ammonium formed in a different location to the process station.

As discussed in Sect. 3.2, the tracer additions did not affect the ammonium uptake rates. At low ambient ammonium concentrations, ammonium uptake was lower than at high ambient ammonium concentrations. This confirms that the shift of preference to ammonium is at least partly due to 
increased concentrations of ammonium. In contradiction to studies which have observed a fairly constant nitrate uptake in the presence of ammonium (Whitehouse et al., 2011), the winter data set shows that nitrate uptake decreases when ammonium concentration increases. This indicates that inhibition of nitrate uptake could also be contributing to shifting the nitrogen uptake regime.

\section{Conclusions}

The seasonality of nitrogen uptake in the Southern Ocean was investigated. Two cruises were conducted: one in winter (July-August 2012) along the GoodHope line and one in late summer within the subantarctic zone (FebruaryMarch 2013). Nitrate uptake rates were similar for both cruises, but ammonium uptake rates were generally greater during the summer cruise. These nitrate uptake rates were, however, lower than rates measured in other cruises undertaken in spring and early summer. Primary production was mainly driven by ammonium during both seasons. While the regions between the ACC fronts are often considered to be uniform in terms of biogeography and phytoplankton distribution, this study shows that this is not the case when considering nitrogen dynamics. Nitrogen uptake is probably driven by more than a simple linear combination of environmental parameters. During the winter cruise, nitrogen uptake rates decreased southwards and were limited by light rather than by nutrients. During this season, the presence of ammonium was shown to shift the nitrogen uptake regime towards increased ammonium uptake. This was a result of both inhibition of nitrate uptake by ammonium as well as concentration effects increasing ammonium uptake. During the summer, on the other hand, nutrient availability seemed to be the most important control. With increased vertical mixing and increased nutrients, nitrogen uptake rates increased even though deepening mixed layers mean that the light conditions are less favourable. Wider observational studies are required to be able to resolve the seasonality behind nutrient fluxes and phytoplankton biogeochemistry as shipboard measurements offer only a snapshot view. It is recommended that winter cruises along the GoodHope line are more frequent in the future and that this data set is the first of a time series which will contribute to the improvement of biogeochemical models for the Southern Ocean.

\section{The Supplement related to this article is available online at doi:10.5194/os-11-251-2015-supplement.}

Author contributions. R. Philibert and H. Waldron conducted the field experiments during the winter cruise. R. Philibert performed the data processing and statistical analyses. R. Philibert wrote the manuscript with inputs from all the authors.
Acknowledgements. This work was supported through the EU FP7 Greenseas programme. R. Philibert has been supported by bursaries under SAMMOC, a joint SANAP-NRF programme and the University of Cape Town. The authors thank SANAP for their support during the research voyage and Raymond Roman for nutrient analyses. The authors acknowledge M. J. Gibberd and Nina Lester for conducting the sampling during the summer cruise. R. Philibert thanks the MicroB3 consortium for the workshop on multivariate statistics. R. Philibert would also like to thank S. Thomalla for the hydrographic, POC and PON data. We would also like to thank the anonymous reviewers from their extremely helpful comments.

Edited by: M. Hoppema

\section{References}

Ansorge, I., Speich, S., Lutjeharms, J., Goni, G., Rautenbach, C. d. W., Froneman, P., Rouault, M., and Garzoli, S.: Monitoring the oceanic flow between Africa and Antarctica: report of the first GoodHope cruise : research in action, S. Afr. J. Sci., 101, 29-35, 2005.

Behrenfeld, M. J.: Abandoning Sverdrup's Critical Depth Hypothesis on phytoplankton blooms, Ecology, 91, 977-989, doi:10.1890/09-1207.1, 2010.

Berman-Frank, I., Cullen, J. T., Shaked, Y., Sherrell, R. M., and Falkowski, P. G.: Iron availability, cellular iron quotas, and nitrogen fixation in Trichodesmium, Limnol. Oceanogr., 46, 12491260, doi:10.4319/lo.2001.46.6.1249, 2001.

Bianchi, M., Feliatra, F., Tréguer, P., Vincendeau, M.-A., and Morvan, J.: Nitrification rates, ammonium and nitrate distribution in upper layers of the water column and in sediments of the Indian sector of the Southern Ocean, Deep-Sea Res. Pt. II, 44, 10171032, doi:10.1016/S0967-0645(96)00109-9, 1997.

Bissett, W., Walsh, J., Dieterle, D., and Carder, K.: Carbon cycling in the upper waters of the Sargasso Sea: I. Numerical simulation of differential carbon and nitrogen fluxes, Deep-Sea Res. Pt. I, 46, 205-269, doi:10.1016/S0967-0637(98)00062-4, 1999.

Borcard, D., Gillet, F., and Legendre, P.: Numerical ecology with R, 9-30, Springer, New-York 2011.

Boyd, P.: Environmental factors controlling phytoplankton processes in the Southern Ocean, J. Phycol., 38, 844-861, doi:10.1046/j.1529-8817.2002.t01-1-01203.x, 2002.

Boyd, P. W., Strzepek, R., Fu, F., and Hutchins, D. A.: Environmental control of open-ocean phytoplankton groups: Now and in the future, Limnol. Oceanogr., 55, 1353-1376, doi:10.4319/lo.2010.55.3.1353, 2010.

Bronk, D. A., Gilbert, P. M., and Ward, B. B.: Nitrogen uptake, dissolved organic nitrogen release, and new production, Science, 265, 1843-1846, doi:10.1126/science.265.5180.1843, 1994.

Cavagna, A.-J., Elskens, M., Griffiths, F. B., Fripiat, F., Jacquet, S. H., Westwood, K. J., and Dehairs, F.: Contrasting regimes of production and potential for carbon export in the Sub-Antarctic and Polar Frontal Zones south of Tasmania, Deep-Sea Res. Pt. II, 58, 2235-2247, doi:10.1016/j.dsr2.2011.05.026, 2011.

Clark, D. R., Rees, A. P., and Joint, I.: A method for the determination of nitrification rates in oligotrophic marine seawater by 
gas chromotography/mass spectrometry, Mar. Chem., 103, 8496, doi:10.1016/j.dsr2.2011.05.026, 2007.

Cochlan, W. P.: Nitrogen uptake in the Southern Ocean, in: Nitrogen in the marine environment, edited by: Capone, D. G., Bronk, D. A., Mulholland, M. R., and Carpenter, E. J., Chap. 12, 569-596, Academic Press, San Diego, doi:10.1016/B978-0-12372522-6.00012-8, 2008.

Collos, Y.: Calculations of $15 \mathrm{~N}$ uptake rates by phytoplankton assimilating one or several nitrogen sources, International Journal of Radiation Applications and Instrumentation. Part A. Applied Radiation and Isotopes, 38, 275-282, doi:10.1016/08832889(87)90038-4, 1987.

Cota, G., Smith, W., Nelson, D., Muench, R., and Gordon, L.: Nutrient and biogenic particulate distributions, primary productivity and nitrogen uptake in the Weddell-Scotia Sea marginal ice zone during winter, J. Mar. Res., 50, 155-181, doi:10.1357/002224092784797764, 1992.

De Baar, H., Buma, A., Nolting, R., Cadée, G., Jacques, G., and Tréguer, P.: On iron limitation of the Southern Ocean: Experimental observations in the Weddell and Scotia Seas, Marine Ecology Progress Series, 65, 105-122, 1990.

DiFiore, P. J., Sigman, D. M., and Dunbar, R. B.: Upper ocean nitrogen fluxes in the Polar Antarctic Zone: Constraints from the nitrogen and oxygen isotopes of nitrate, Geochem. Geophy. Geosys., 10, Q11016, doi:10.1029/2009GC002468, 2009.

Dugdale, R. C. and Goering, J. J.: Uptake of new and regenerated forms of nitrogen in primary productivity, Limnol. Oceanogr., 12, 196-206, doi:10.4319/lo.1967.12.2.0196, 1967.

Elskens, M., Baeyens, W., Brion, N., Galan, S. D., Goeyens, L., and Brauwere, A. D.: Reliability of $\mathrm{N}$ flux rates estimated from ${ }^{15} \mathrm{~N}$ enrichment and dilution experiments in aquatic systems, Global Biogeochem. Cy., 19, GB4028, doi:10.1029/2004GB002332, 2005.

Eppley, R., Sharp, J., Renger, E., Perry, M., and Harrison, W.: Nitrogen assimilation by phytoplankton and other microorganisms in the surface waters of the central North Pacific Ocean, Mar. Biol., 39, 111-120, doi:10.1007/BF00386996, 1977.

Eppley, R. W. and Peterson, B. J.: Particulate organic matter flux and planktonic new production in the deep ocean, Nature, 282, 677-680, doi:10.1038/282677a0, 1979.

Falkowski, P., Laws, E., Barber, R., and Murray, J.: Chapter 4 - Phytoplankton and their role in primary, new and export production, in: Ocean biogeochemistry: The role of the ocean carbon cycle in global change, edited by: Fasham, M., Springer, 2003.

Falkowski, P. G., Barber, R. T., and Smetacek, V.: Biogeochemical controls and feedbacks on ocean primary production, Science, 281, 200-206, doi:10.1126/science.281.5374.200, 1998.

Gandhi, N., Ramesh, R., Laskar, A., Sheshshayee, M., Shetye, S., Anilkumar, N., Patil, S., and Mohan, R.: Zonal variability in primary production and nitrogen uptake rates in the southwestern Indian Ocean and the Southern Ocean, Deep-Sea Res. Pt. I, 67, 32-43, doi:10.1016/j.dsr.2012.05.003, 2012.

Glibert, P. M., Lipschultz, F., McCarthy, J. J., and Altabet, M. A.: Isotope dilution models of uptake and remineralization of ammonium by marine plankton, Limnol. Oceanogr., 27, 639-650, doi:10.4319/lo.1982.27.4.0639, 1982.

Glibert, P. M., Lipschultz, F., McCarthy, J. J., and Altabet, M. A.: Has the mystery of the vanishing ${ }^{15} \mathrm{~N}$ in isotope dilution ex- periments been resolved?, Limnol. Oceanogr., 30, 444-447, doi:10.4319/lo.1985.30.2.0444, 1985.

Goeyens, L., Tréguer, P., Baumann, M., Baeyens, W., and Dehairs, F.: The leading role of ammonium in the nitrogen uptake regime of Southern Ocean marginal ice zones, J. Marine Syst., 6, 345361, doi:10.1016/0924-7963(94)00033-8, 1995.

Grasshoff, K., Ehrhardt, M., and Kremling, K.: Methods of seawater analysis, Verlag Chemie, Weinheim, Germany, 1983.

Gruber, N., Gloor, M., Fletcher, S. E. M., Doney, S. C., Dutkiewicz, S., Follows, M. J., Gerber, M., Jacobson, A. R., Joos, F., Lindsay, K., Menemenlis, D., Mouchet, A., Müller, S. A., Sarmiento, J. L., , and Takahashi, T.: Oceanic sources, sinks, and transport of atmospheric $\mathrm{CO}_{2}$, Global Biogeochem. Cy., 23, GB1005, doi:10.1029/2008GB003349, 2009.

Hedges, J., Baldock, J., Gélinas, Y., Lee, C., Peterson, M., and Wakeham, S.: The biochemical and elemental compositions of marine plankton: A NMR perspective, Mar. Chem., 78, 47-63, doi:10.1016/S0304-4203(02)00009-9, 2002.

Henson, S. A., Sanders, R., Madsen, E., Morris, P. J., Le Moigne, F., and Quartly, G. D.: A reduced estimate of the strength of the ocean's biological carbon pump, Geophys. Res. Lett., 38, L04606, doi:10.1029/2011GL046735, 2011.

Hoffmann, L., Peeken, I., and Lochte, K.: Iron, silicate, and light colimitation of three Southern Ocean diatom species, Polar Biol., 31, 1067-1080, doi:10.1007/s00300-008-0448-6, 2008.

Holmes, R. M., Aminot, A., Kérouel, R., Hooker, B. A., and Peterson, B. J.: A simple and precise method for measuring ammonium in marine and freshwater ecosystems, Can. J. Fish. Aqua. Sci., 56, 1801-1808, doi:10.1139/f99-128, 1999.

Hutchins, D., Sedwick, P., DiTullio, G., Boyd, P., Queguiner, B., Griffiths, F., and Crossley, C.: Control of phytoplankton growth by iron and silicic acid availability in the subantarctic Southern Ocean: Experimental results from the SAZ Project, J. Geophys. Res.-Oceans, 106, 31559-31572, doi:10.1029/2000JC000333, 2001.

Joubert, W. R., Thomalla, S. J., Waldron, H. N., Lucas, M. I., Boye, M., Le Moigne, F. A. C., Planchon, F., and Speich, S.: Nitrogen uptake by phytoplankton in the Atlantic sector of the Southern Ocean during late austral summer, Biogeosciences, 8, 29472959, doi:10.5194/bg-8-2947-2011, 2011.

Kanda, J., Laws, E., Saino, T., and Hattori, A.: An evaluation of isotope dilution effect from conventional data sets of $15 \mathrm{~N}$ uptake experiments, J. Plankton Res., 9, 79-90, doi:10.1093/plankt/9.1.79, 1987.

Laws, E.: Isotope dilution models and the mystery of the vanishing 15-N, Limnol. Oceanogr., 29, 379-386, doi:10.4319/lo.1984.29.2.0379, 1984.

Laws, E. A., Falkowski, P. G., Smith, W. O., Ducklow, H., and McCarthy, J. J.: Temperature effects on export production in the open ocean, Global Biogeochem. Cy., 14, 1231-1246, doi:10.1029/1999GB001229, 2000.

Le Moigne, F. A. C., Boye, M., Masson, A., Corvaisier, R., Grossteffan, E., Guéneugues, A., and Pondaven, P.: Description of the biogeochemical features of the subtropical southeastern Atlantic and the Southern Ocean south of South Africa during the austral summer of the International Polar Year, Biogeosciences, 10, 281-295, doi:10.5194/bg-10-281-2013, 2013.

Lomas, M. W. and Glibert, P. M.: Temperature regulation of nitrate uptake: A novel hypothesis about nitrate uptake and re- 
duction in cool-water diatoms, Limnol. Oceanogr., 3, 556-572, doi:10.4319/lo.1999.44.3.0556, 1999.

Martin, J. H., Gordon, R. M., and Fitzwater, S. E.: Iron in Antarctic waters, Nature, 345, 156-158, doi:10.1038/345156a0, 1990.

Mitchell, B. G., Brody, E. A., Holm-Hansen, O., McClain, C., and Bishop, J.: Light limitation of phytoplankton biomass and macronutrient utilization in the Southern Ocean, Limnol. Oceanogr., 36, 1662-1677, doi:10.4319/lo.1991.36.8.1662, 1991.

Moore, C. M., Hickman, A. E., Poulton, A. J., Seeyave, S., and Lucas, M. I.: Iron-light interactions during the CROZet natural iron bloom and EXport experiment (CROZEX): Taxonomic responses and elemental stoichiometry, Deep-Sea Res. Pt. II, 54, 2066-2084, doi:10.1016/j.dsr2.2007.06.015, 2007.

Orsi, A., Whitworth, T., and Nowlin, W.: On the meridional extent and fronts of the Antarctic Circumpolar Current, Deep-Sea Res. Pt. I, 42, 641-673, doi:10.1016/0967-0637(95)00021-W, 1995.

Pollard, R., Lucas, M., and Read, J.: Physical controls on biogeochemical zonation in the Southern Ocean, Deep-Sea Res. Pt. II, 49, 3289-3305, doi:10.1016/S0967-0645(02)00084-X, 2002.

Reay, D. S., Priddle, J., Nedwell, D. B., Whitehouse, M. J., EllisEvans, J. C., Deubert, C., and Connelly, D. P.: Regulation by low temperature of phytoplankton growth and nutrient uptake in the Southern Ocean, Marine Ecology Progress Series, 219, 51-64, doi:10.3354/meps219051, 2001.

Redfield, A. C.: On the proportions of organic derivatives in sea water and their relation to the composition of plankton, University Press of Liverpool, 1934.

Sambrotto, R. N. and Mace, B. J.: Coupling of biological and physical regimes across the Antarctic Polar Front as reflected by nitrogen production and recycling, Deep-Sea Res. Pt. II, 47, 33393367, doi:10.1016/S0967-0645(00)00071-0, 2000.

Sanders, R., Morris, P. J., Stinchcombe, M., Seeyave, S., Venables, H., and Lucas, M.: New production and the f ratio around the Crozet Plateau in austral summer 2004/2005 diagnosed from seasonal changes in inorganic nutrient levels, Deep-Sea Res. Pt. II, 54, 2191-2207, doi:10.1016/j.dsr2.2007.06.007, 2007.

Sarmiento, J. L., Gruber, N., Brzezinski, M. A., and Dunne, J. P.: High-latitude controls of thermocline nutrients and low latitude biological productivity, Nature, 427, 56-60, doi:10.1038/nature02127, 2004.

Savoye, N., Dehairs, F., Elskens, M., Cardinal, D., Kopczyńska, E., Trull, T. W., Wright, S., Baeyens, W., and Griffiths, F. B.: Regional variation of spring $\mathrm{N}$-uptake and new production in the Southern Ocean, Geophys. Res. Lett., 31, L03301, doi:10.1029/2003GL018946, 2004.

Sedwick, P., Blain, S., Quéguiner, B., Griffiths, F., Fiala, M., Bucciarelli, E., and Denis, M.: Resource limitation of phytoplankton growth in the Crozet Basin, Subantarctic Southern Ocean, Deep-Sea Res. Pt. II, 49, 3327-3349, doi:10.1016/S09670645(02)00086-3, 2002.

Semeneh, M., Dehairs, F., Elskens, M., Baumann, M., Kopczynska, E., Lancelot, C., and Goeyens, L.: Nitrogen uptake regime and phytoplankton community structure in the Atlantic and Indian sectors of the Southern Ocean, J. Marine Syst., 17, 159-177, doi:10.1016/S0924-7963(98)00036-0, 1998a.

Semeneh, M., Dehairs, F., Fiala, M., Elskens, M., and Goeyens, L.: Seasonal variation of phytoplankton community structure and ni- trogen uptake regime in the Indian Sector of the Southern Ocean, Polar Biol., 20, 259-272, doi:10.1007/s003000050302, 1998 b.

Smart, S. M., Fawcett, S. E., Thomalla, S. J., Weigand, M. A., Reason, C. J. C., and Sigman, D. M.: Isotopic evidence for nitrification in the Antarctic winter mixed layer, Global Biogeochem. Cy., submitted, 2015.

Smith Jr., W. and Harrison, W.: New production in polar regions: The role of environmental controls, Deep-Sea Res. Pt. I, 38, 1463-1479, doi:10.1016/0198-0149(91)90085-T, 1991.

Smith Jr., W. and Nelson, D. M.: Phytoplankton growth and new production in the Weddell Sea marginal ice zone in the austral spring and autumn, Limnol. Oceanogr., 35, 809-821, doi:10.4319/lo.1990.35.4.0809, 1990.

Strzepek, R. F., Hunter, K. A., Frew, R. D., Harrison, P. J., and Boyd, P. W.: Iron-light interactions differ in Southern Ocean phytoplankton, Limnol. Oceanogr., 57, 1182-1200, doi:10.4319/lo.2012.57.4.1182, 2012.

Sverdrup, H.: On conditions for the vernal blooming of phytoplankton, J. Conseil, 18, 287-295, doi:10.1093/icesjms/18.3.287, 1953.

Takahashi, T., Sutherland, S. C., Wanninkhof, R., Sweeney, C., Feely, R. A., Chipman, D. W., Hales, B., Friederich, G., Chavez, F., Sabine, C., Watson, A., Bakker, D. C., Schuster, U., Metzl, N., Yoshikawa-Inoue, H., Ishii, M., Midorikawa, T., Nojiri, Y., Körtzinger, A., Steinhoff, T., Hoppema, M., Olafsson, J., Arnarson, T. S., Tilbrook, B., Johannesen, T., Olsen, A., Bellerby, R., Wong, C., Delille, B., Bates, N., and De Baar, H.: Climatological mean and decadal change in surface ocean $p \mathrm{CO}_{2}$, and net seaair $\mathrm{CO}_{2}$ flux over the global oceans, Deep-Sea Res. Pt. II, 56, 554-577, doi:10.1016/j.dsr2.2008.12.009, 2009.

Taylor, B. W., Keep, C. F., Hall, Robert O., J., Koch, B. J., Tronstad, L. M., Flecker, A. S., and Ulseth, A. J.: Improving the fluorometric ammonium method: Matrix Effects, background Fluorescence, and standard additions, J. N. Am. Benthol. Soc., 26, 167177, doi:10.1899/0887-3593(2007)26[167:ITFAMM]2.0.CO;2, 2007.

Thomalla, S. J., Fauchereau, N., Swart, S., and Monteiro, P. M. S.: Regional scale characteristics of the seasonal cycle of chlorophyll in the Southern Ocean, Biogeosciences, 8, 2849-2866, doi:10.5194/bg-8-2849-2011, 2011 a.

Thomalla, S. J., Waldron, H. N., Lucas, M. I., Read, J. F., Ansorge, I. J., and Pakhomov, E.: Phytoplankton distribution and nitrogen dynamics in the southwest indian subtropical gyre and Southern Ocean waters, Ocean Sci., 7, 113-127, doi:10.5194/os-7-1132011, $2011 b$.

Thomalla, S., Atwood, C., Baderoen, G., Bilana, S., Bone, E., Botha, A., Plessis, M. D., Fyfe, A., Gibberd, M.-J., Harington, A., Horsten, N., Joubert, W., Lester, N., Lobelle, D., Mtshali, T., Needham, D., Nohayi, L., Packer, K., Preston-Whyte, F., Rehm, E., Rentel, R., Smart, S., Smit, J.-P., von der Heyden, B., Roychoudhury, A., Ansorge, I., Lucas, M., Waldron, H., Swart, S., and Monteiro, P.: The Southern Ocean Seasonal Cycle Experiment (SOSCEx) - Summer Cruise Report: MV SA Agulhas - Voyage 004b 15 February-11 March 2013, available at: http://greenport.nersc.no/documents/12099/21370/ SOSCExCruiseReport.pdf (last access:10 March 2015), 2013.

Tilzer, M. and Dubinsky, Z.: Effects of temperature and day length on the mass balance of Antarctic phytoplankton, Polar Biol., 7, 35-42, doi:10.1007/BF00286822, 1987. 
Van Oijen, T., Van Leeuwe, M., Granum, E., Weissing, F., Bellerby, R., Gieskes, W., and De Baar, H.: Light rather than iron controls photosynthate production and allocation in Southern Ocean phytoplankton populations during austral autumn, J. Plankton Res., 26, 885-900, doi:10.1093/plankt/fbh088, 2004.

Venables, H. and Moore, C. M.: Phytoplankton and light limitation in the Southern Ocean: Learning from high-nutrient, high-chlorophyll areas, J. Geophys. Res., 115, C02015, doi:10.1029/2009JC005361, 2010.

Venables, H. J., Clarke, A., and Meredith, M. P.: Wintertime controls on summer stratification and productivity at the western Antarctic Peninsula, Limnol. Oceanogr., 58, 1035-1047, doi:10.4319/lo.2013.58.3.1035, 2013.

Vernet, M., Kozlowski, A., Yarmey, L., Lowe, A., Ross, R., Quetin, L., and Fritsen, C.: Primary production throughout austral fall, during a time of decreasing daylength in the western Antarctic Peninsula, Marine Ecology Progress Series, 452, 45-61, doi:10.3354/meps09704, 2012.

Vichi, M., Masina, S., and Navarra, A.: A generalized model of pelagic biogeochemistry for the global ocean ecosystem. Part II: Numerical simulations, J. Marine Syst., 64, 110-134, doi:10.1016/j.jmarsys.2006.03.014, 2007.

Volk, T. and Hoffert, M. I.: Ocean carbon pumps: Analysis of relative strengths and efficiencies in ocean-driven atmospheric $\mathrm{CO}_{2}$ changes, Geoph. Monog. Series, 32, 99-110, 1985.
Waldron, H. N., Attwood, C. G., Probyn, T. A., and Lucas, M. I.: Nitrogen dynamics in the Bellingshausen Sea during the Austral spring of 1992, Deep-Sea Res., 42, 1253-1276, doi:10.1016/0967-0645(95)00063-V, 1995.

Ward, B. B., Kilpatrick, K. A., Renger, E. H., and Eppley, R. W. Biological nitrogen cycling in the nitracline, Limnol. Oceanogr., 34, 493-513, doi:10.4319/lo.1989.34.3.0493, 1989.

Westwood, K. J., Griffiths, F. B., Webb, J. P., and Wright, S. W.: Primary production in the Sub-Antarctic and Polar Frontal Zones south of Tasmania, Australia; SAZ-Sense survey, 2007, DeepSea Res. Pt. II, 58, 2162-2178, doi:10.1016/j.dsr2.2011.05.017, 2011.

Whitehouse, M. J., Atkinson, A., and Rees, A.: Close coupling between ammonium uptake by phytoplankton and excretion by Antarctic krill, Euphausia superba, Deep-Sea Res. Pt. I, 58, 725732, doi:10.1016/j.dsr.2011.03.006, 2011.

Yool, A., Martin, A. P., Fernández, C., and Clark, D. R.: The significance of nitrification for oceanic new production, Nature, 447, 999-1002, doi:10.1038/nature05885, 2007. 